\title{
ROYAL WEDDINGS AND THE GRAND VEZIRATE: INSTITUTIONAL AND SYMBOLIC CHANGE IN THE EARLY EIGHTEENTH CENTURY
}

\author{
Tülay Artan
}

A city is never neutral: the urban fabric is a device for tracking, measuring, controlling, and predicting behaviour over space and time," writes Donald Preziosi in his Introduction to a commendable compilation on The Ottoman City and Its Parts. "Ideology and urban structure are not external to each other," he continues: Cities and their parts do not just "exemplify, embody, and express, but at the same time enforce, perpetuate, and engender relations of power. ${ }^{1}$

A case in point is the intricate relationship that evolved over the first quarter of the 18th century between the Ottoman court and the urban space of the capital. Around this time, there emerged (or re-emerged) a specific variety of court festival which, at least in part, was played out on the streets and squares of İstanbul. This came after a long 17thcentury crisis had entailed a break with previous Ottoman rites of power in the shape that they had assumed in the 16th century. Hence the early 18 th-century practices represented both a return to the past and something new, with their innovative side being introduced, as would seem to be the case with all such moments of "the invention of tradition," under the guise of conformity with ancient law and custom (kanûn-ı kadìm). Thus it was not altogether new for royal princesses to be married off to high-ranking dignitaries, or for their weddings to be organised on a vast and sumptuous scale. ${ }^{2}$ But first, such ostentatious

${ }^{1}$ Donald Preziosi, 'The Mechanisms of Urban Meaning', in: The Ottoman City and Its Parts, I.A. Bierman, R.A. Abou-el-Haj and D. Preziosi, eds. (New York 1991) p. 5 .

${ }^{2} 16$ th- and 17 th-century marriage celebrations and processions are narrated briefly in period chronicles. One interesting account is that of Grand Vezir İbrahim Pasha's marriage to the grand-daughter of a by-then deceased prominent political figure. It was celebrated over several weeks, starting in May 1524 and the Hippodrome thus became a new ceremonial stage. Despite repeated assertations in modern scholarship that the bride was a sister of Süleyman I, two new challenges were necently raised to this assertion. Compare: Ebru Turan, The Sultan's Favourite: Ibrahim Pasha and the Making of the Ottoman Universal Sovereignty in the Reign of Sultan Süleyman (1516-1526), unpub. PhD Diss., Chicago University (Chicago 2007) pp. 137-139 and 
weddings had fallen into social neglect and disuse for a hundred years or so (except for a single occasion in 1675 , and then not in İstanbul but Edirne). Second, when and as they appeared to be revived, they came to be organised not just on a vaster scale than in earlier periods, but also in a qualitatively new way that spread and expanded beyond the confines of the Topkapi and other, lesser palaces in the historical peninsula. Linking these palaces together, urban centers and public thoroughfares evolved into the stage and decor of the pageantries. Paramount in this regard were processions bearing (a) betrothal tokens (alay-ı nişân), (b) trousseaus (alay-ı cihâzz), and (c) the brides themselves (alay-ı arûs), all of which now achieved a degree of visibility that was much more accessible to, and consumable by, the populace.

Our evidence for these processions and other celebrations comes mostly from various histories, annals or chronicles, as well as festival books called sûrnâmes in Ottoman Turkish. ${ }^{3}$ Early in the 18th century, at least some of these manuscripts came to mention the weddings of royal princesses more frequently and in relatively greater detail. This is significant in itself, and is the court narrative counterpart to the enhanced visibility mentioned above. Nevertheless, it is to a specific sûrname that we must turn for truly comprehensive coverage: one in the Nationalbibliothek in Vienna that sheds light on the triple wedding organised by the powerful grand vezir (Nevşehirli) Damad Ibrahim Pasha for three of Ahmed III's (r. 1703-1730) many daughters in

210-223, and Zeynep Yelçe, 'Evaluating Three Imperial Festivals: 1524, 1530, 1539', in: Celebration, Entertainment and Theater in the Ottoman World, Suraiya Faroqhi and Arzu Öztürkmen, eds. (forthcoming).

${ }^{3}$ For an exhaustive bibliography on the 18th-century sûrnâmes: Hatice Aynur, The Wedding Ceremony of Saliha Sultan: 1834, 2 vols (Duxburry 1995) pp. 2-5. For various documents, archival and narrative, on the marriage ceremonies during the reign of Ahmed III: M. Çağatay Uluçay, 'Beş Yaşında İken Nikâhlanan ve Beşikte Nişânlanna Sultanlar', Yeni Tarih Dergisi I (1957) pp. 103-107; idem, 'Fatma ve Safiye Sultanların Düğünlerine Ait Bir Araştırma', İstanbul Enstitüsü Mecmuası IV (1958) pp. 139-148; Mehmet Arslan, 'III. Ahmed'in Kızı Fatma Sultan'ın Düğünü Üzerine Bir Belge', in: Osmanl Makaleleri. Edebiyat, Tarih, Kültür (İstanbul 2000) pp. 527-552; idem, 'II. Mustafa'nın Kızları Ayșe Sultan ve Emine Sultan'ın Düğünleri Üzerine Bir Belge', in: Osmanl Makaleleri, pp. 553-566; idem, 'II. Mustafa'nın Kızı Safiye Sultan'ın Düğünü Üzerine Bir Belge', in Osmanl Makaleleri, pp. 567-574. For a transcription, translation and a facsimile of the 1720 festival: Mertol Tulum, 'Çeviri Yazılı Metin', in: Sûrnâme. III. Ahmed'in Düğün Kitabı (Bern 2000) pp. 221-308. For a textual analysis, critical edition and facsimile of a 19th-century marriage ceremony: Aynur, The Wedding Ceremony of Saliha Sultan. 
early $1724 .{ }^{4}$ This was when Hadice (1710-1738), 'Atîke (1712-1737), and Ümmügülsüm (1708-1732) were married: the first to a prominent provincial governor (Hafiz Ahmed Pasha), the son of a distinguished vezir, a royal-damad and a close companion of the current grand vezir; ${ }^{5}$ the second and third, more significantly, to a son (Genç Mehmed Pasha) and a nephew (Tevkîî il Ali Pasha) of the said Damad Ibrahim Pasha. ${ }^{6}$

The celebrations, lasting from 20 February to 16 March, comprised not only many indoor activities (situated in the Topkapı Palace as well as the three palaces allocated to the royal brides in question), but also a total of nine imperial processions, meaning three each of alay-ı nişân, alay-ı cihâz, and alay-ı arûs. By tracing the routes they took through the Imperial Gate (Bâb-ı Hümâyûn) to their ultimate destinations, I will be arguing that they were not only court festivals but at least partly in the nature of an invented tradition of urban festivities, too, even if they did not grow from below, from a point of origin located in popular culture. Moreover, I shall be showing that these processions became part and parcel of the grand vezir's designs to gain public recognition, acclaim and approval. This had to do with the way they were centered on the ancient Hippodrome (called Atmeydan in literal translation). As they were made to move in and out of this single most urban core of the Ottoman capital, the grand vezir's palace and household were

${ }^{4}$ Österreichische National Bibliothek (Vienna), Codex Vindobonensis Palatinus HO 95: G. Flügel, Die arabischen, persischen und türkischen Handscriften der Kaiserlichköniglichen Hofbibliothek zu Wien, vol. 2 (Vienna 1865) p. 289.

5 At the time, Hafiz Ahmed Pasha was the governor of Sayda. He was the son of Çerkes Küçük (Sinek) (Silâhdâr) Osman Pasha (d. 1727), then the governor of Damascus, who himself had married a princess in 1720. According to the French Ambassador Marquie de Bonnac, Osman Pasha was an intimate friend of the grand vezir: M. Charles Schefer, Mémoire historique sur l'Ambassade de France a Constantinople. Par le Marquie de Bonnac. Publié avec un précis de ses négociations a la porte ottomane (Paris 1894) p. xxix. There is some confusion in the secondary literature regarding (Küçük) Sinek Osman Pasha himself being married to a princess. Mehmed Süreyya noted that he was engaged to Emetullâh Sultan, a daughter of Mustafa II: Mehmed Süreyya, Sicill-i Osmani 4, Nuri Akbayar, ed. (İstanbul 1996) p. 1307. But Osman Pasha who married Emetullâh Sultan in 1720 was actually Sirke Osman Pasha (d. 1723), originally from Kanije: Süreyya, Sicill-i Osmanî 4, p. 1308. For the 1720 marriage: Mehmed Râşid/İsmâil 'Âsım Küçükçelebizâde, Tarih-i Râşid / Tarih-i İsmail 'Âsım Küçükçelebizâde V (İstanbul, 1282 [1865]) p. 225. See also: İsmail Hakkı Uzunçarşıllı, Osmanlı Devletinin Merkez ve Bahriye Teşkilatı (Ankara 1988 [1948]) p. 250ff; for the brides: M. Çağatay Uluçay, Padişahların Kadınları ve Kizları (Ankara 1980) p. 78.

${ }^{6}$ Mehmed Râşid, Tarih-i Râşid V, pp. 90-92, 97-101. 
also put on display, and loom large in connection with these processions. Hence I will also be revisiting some long-standing convictions regarding the separation of the grand vezir's office from the imperial household.

\section{Ottoman Royal Marriages in the 15th and Early 16th Centuries}

Before that, however, something needs to be said about the previous history of Ottoman royal marriages within the framework of dynastic structures and procedures in general. As with all other social institutions or practices, there was no such thing as a single type or model of royal marriage that remained static over time. On the contrary: the sultans' own marriage policies were constantly undergoing change and evolution in the context of all the different power configurations that kept emerging and receding within and around Ottoman society-and so were policies and practices regarding the female members of the House of Osman, including their prospective bridegrooms, and the rituals and ceremonies that crowned their marriages. In other words, it was nothing new for a role to be found for princesses in this tangled web of matrimonial alliances; rather, it was the specific definition of this role and function that would be the subject of fresh codifications from around 1700 onwards.

Much earlier, in a formative phase when the leaders of the small but rising emirate had not yet been led or constrained to take only slave consorts for themselves, the various princes (and their mothers coming from dynasties of more or less equal stature with the Ottomans) had to some extent shared power with the sultan. Similarly, Ottoman princesses for their part had usually been married to the sons of these dynasties, as well as to influential statesmen (or their offspring) who in one way or another had gathered around the House of Osman. Such practices had not simply ceased to exist with the conquest of Constantinople and Mehmed II's relative "despotisation of the sultanate," as evidenced by some of the matrimonial alliances arranged for and through the sons and daughters of Bayezid II (r. 1481-1512).

In time, however, the Ottomans did find themselves standing alone in a space they had largely cleared of all possible rivals, and the previous custom of marrying their princesses to princes of comparable dynasties was gradually abandoned. Instead, in the 16th century even greater importance came to be attached to sultans' daughters in terms 
of ensuring the support of the highest-ranking office holders like grand vezirs and grand admirals. Starting with Selim I (r. 1512-20), these frequent marriages of Ottoman princesses to a succession of appointees of vezirial rank functioned as a way of coopting "established stars" amongst the top office holders-even though the designated husbands in question were rather old, and were likely to be replaced by men of more or less the same generation. ${ }^{7}$ For if the chosen bridegroom was killed or else died of natural causes (though people did not frequently die of old age in those days), the princess in question would be married off to another top dignitary regardless of her or his age.

In any case, like royal births and circumcisions, these weddings were celebrated through parades and other spectacles designed for public consumption-as well as acrobatic performances, sporting competitions, theatrical shows, nightly entertainments and stately banquets that all took place in the privacy of the imperial palace. There is, however, a paradox, in that in stark contrast to all these massive celebrations and festivities, at least part of which were very much in the public eye, the same royal marriages, including especially the names of the royal women who were being married off, went unrecorded and unreported in period chronicles. Princesses' marriages were private, family affairs. In 1539, for example, a famous circumcision festival was organized for the sons of Süleyman I. Simultaneously, Süleyman I gave his only daughter Mihrümah in marriage to Rüstem Pasha. ${ }^{8}$ Strikingly, Celâlzâde, Solakzâde or Peçevi all wax eloquent on the

${ }^{7}$ It is curious to note that once, on 8 December 1515 , the sultan, angered by his vezirs at an Imperial Council meeting, ordered all princesses to be married. He was so furious that in the next eight days, he left for hunting and did not convene the Imperial Council: Şehr-i zilkade el-şerife, sene 921: “İkinci gününde divan olub Hüdavendigar vüzeraya münkesir olub ne mikdar dul şehzâde var ise ere virmek emr olund. Badehu Hüdavendigar şikara süvar olub sekiz gün divan itmedi." Feridun Ahmed Bey, Münşeatü's-selatin, vol. 1, (İstanbul 1858). See note 16 below.

${ }_{8}$ Zeynep Yelçe quotes Hammer (b.3, v.5) who gives the information based on Nicolo Paruta's reports (DIEZ no.31 in Staatsbibliothek Berlin Preußischer Kulturbesitz). Paruta mentions that the wedding of the sultan's daughter and the circumcision of his sons were at the same time, and elsewhere that the sultan's daughter was married to Rüstem. In fact, such is the quasi-official silence in which it comes to be shrouded, that contemporary Venetian sources report that Rüstem Pasha has been married without saying to whom-a failure to mention Mihrümah Sultan which can only be explained by ignorance-while the much later Sicill-i Osmani goes astray in ascribing the wedding to 1543 , which again reflects the same silence and later ignorance: Süreyya, Sicill-i Osmani 5, p. 1402. See: Yelçe, 'Evaluating Three Imperial Festivals: 1524, 1530, 1539', (forthcoming). 
circumcision displays with the royal wedding being accorded no mention whatsoever.

What was subsequently expected of both the royal bride and her politically successful husband was that they should set up pious endowments so as to visibly channel funds into works of public faith and charity that would merge with and complement the efforts of the sultan himself in this regard. ${ }^{9}$ Such endowments and works, in other words, became material emblems of the alliance, the bonding between the ruler and the rest of his elite. In return, however, the sultan promised neither loyalty nor kinship. At the end of the day, being a royal in-law was no guarantee that anyone would be able to keep his head. And dynastic continuity through the female side of the Ottoman line was out of the question.

To this there corresponded a certain configuration of the capital city, and of the way the ruling house and the rest of the elite were inscribed into that urban space. The functions of early modern court cities and/or capitals basically included: attracting settlement and providing a habitat; embodying ideological, social and political control in space; creating venues for charity and worship; and fostering economic development. All these served, in turn, to underscore the power, the piety, and hence the legitimacy of the ruler. ${ }^{10}$ In the Ottoman capitals or court cities of Bursa, Edirne and İstanbul, these functions were institutionalized in and around, first, the royal palace, and second, great imperial socio-religious complexes at the center of each of which stood a major mosque. Both types and sets of buildings incorporated a specific siting, embodied a certain level of grandeur, and were invested with non-random signs and symbols of a royal, dynastic nature.

Architecture constituted a visual language of power accessible to the people. Thus both the Topkapi Palace at the tip of the historical peninsula, ${ }^{11}$ and the great socio-religious complexes on the hill-

9 Tülay Artan, 'Periods and Problems of Ottoman (Women's) Patronage on Via Egnatia', in: The Via Egnatia under Ottoman Rule 1380-1699, Elizabeth Zachariadou, ed. (Rethymnon 1996) pp. 19-43.

${ }^{10}$ Howard Crane, 'The Ottoman Sultan's Mosques. Icons of Imperial Legitimacy', in: The Ottoman City and Its Parts, I.A. Bierman, R.A. Abou-el-Haj and D. Preziosi, eds. (New York 1991) pp. 173-243.

${ }^{11}$ Gülru Necipoğlu, Architecture, Ceremonial, and Power. The Topkapi Palace in the Fifteenth and Sixteenth Centuries (Cambridge, Mass.; London 1991). See also: Gülru Necipoğlu, The Age of Sinan: The Architectural Culture in the Ottoman Empire (Princeton 2005). 
tops overlooking the Golden Horn, came to imprint so many dynastic manifestations on the face of the city, and hence also on the social memory of its inhabitants. ${ }^{12}$ Simultaneously, it was the imperial processions from the royal palace to one or the other of these great imperial mosques (on the occasion of royal visits to ancestral tombs, of a new sultan's ritual girding with a sacred sword, of triumphal re-entries at the conclusion of successful military campaigns, or of Friday prayers), that linked these imperial symbols to one another and placed the Ottoman ruler at center-stage in a carefully contrived theater of power. ${ }^{13}$

\section{Late-16th Century Problems of Legitimation and Changes in Dynastic Politics}

Later in the 16th century, for reasons and in ways that we can here only briefly outline, an enormous crisis engulfed the Ottoman empire. Because of the negative effects of the "paradox of empire", as well as the consequences of operating against stiffening European resistance, Ottoman armies found themselves no longer able to carry off rapid and decisive victories. In terms of dynastic politics the upshot was that it became increasingly risky for sultans to persist in leading from the front in quest of the sort of military-charismatic legitimacy achieved by the likes of Mehmed II, Selim I or Süleyman I. Simply put, the immediate successors of Süleyman I (r. 1520-1566), meaning Selim II, Murad III, and Mehmed III, stopped going on campaigns, and started delegating field command to their grand vezirs. Simultaneously, both urban and rural unrest assumed gigantic proportions. As the royal center weakened, the capital's political elite underwent a comprehensive factionalisation, with each rival group courting the support of the janissaries and the populace, who thereby became so unruly as to

\footnotetext{
12 Gülru Necipoğlu, 'The Süleymaniye Complex in İstanbul: An Interpretation', Muqarnas 3 (1985) pp. 92-118. See also:

${ }_{13}$ Gülru Necipoğlu, 'Dynastic Imprints on the Cityscape: The Collective Message of Imperial Funerary Mosque Complexes in İstanbul', in: İslâm Dünyasında Mezarlıklar ve Defin Gelenekleri (Ankara 1996) pp. 23-36; Cemal Kafadar, 'Eyüp'te Kılıç Kuşanma Törenleri', in: Eyüp: Dün / Bugün, Tülay Artan, ed. (İstanbul 1994) pp. 50-61; Nicolas Vatin, 'Aux origines du pèlerinage à Eyüp des sultans Ottomans', Turcica XXVII (1995) pp. 91-99; Mehmet İpşirli, 'Osmanlılarda Cuma Selamlığı (Halk-Hükümdar Münasebetleri Açısından Önemi)', in: Prof Dr. Bekir Kütükoğlu'na Armağan (İstanbul 1991) pp. 459-471.
} 
constantly threaten the throne, and to render a stable government and policy continuity virtually impossible.

In the provinces, large numbers of former peasants equipped with firearms (who at some point had been recruited into the army, and then had either deserted or been demobilized) swelled the ranks of Celâli rebels. For decades they roamed the countryside under leaders who kept circulating between a number of roles-such as being outlaws, entering the service of this or that local power-holder, emerging as local power-holders themselves, sometimes being coopted into imperial service and even into royal family, and then perhaps continuing in field command or relapsing into banditry, or even being executed. All this translated into a long period of abnormality that extended from the late-16th into the mid-17th century. Only from the late 1650s onwards did some semblance of order begin to be restored, in quite draconian fashion, under Köprülü Mehmed Pasha's strongman rule at the grand vezirate. At the very center or apex of power, this long period of abnormality was reflected in a massive break in dynastic structures and practices, including (i) relations between the sultan, the grand vezir, and other courtiers; (ii) the location of the court itself; (iii) royal marriages; and (iv) all kinds of rites, rituals or ceremonies of power. ${ }^{14}$

First, as already indicated, sultanic legitimacy could no longer be risked on the outcome of uncertain campaigns. Direct military leadership devolved more and more on their grand vezirs. A corollary was that these non-campaigning, or at best infrequently campaigning, sultans could not keep building imperial mosques and surrounding them with socio-religious complexes-since the right to build these was supposed to be earned only through major, personally led victories, and even to be supported at the material, financial level by the spoils of war. ${ }^{15}$ Thus from a certain point onward, there emerged a disparity between the further growth of the Topkapi Palace and the accumulation of mosque complexes punctuating the skyline. The first continued, but the second came to an end. More specifically, the imperial palace kept growing in an organic agglutinative way, with each sultan contributing a loggia of his own to symbolize his sovereignty

14 Tülay Artan, 'Was Edirne a Capital and a Royal Court in the Second Half of the 17th Century?', paper presented at the Voyvoda Caddesi Konuşmaları Series, 16 April 2003.

${ }^{15}$ Crane, 'Ottoman Sultan's Mosques', p. 204. 
and to commemorate his name as part of the royal residence. But this was a relatively private affair going on behind the perimeter walls of the palace. In contrast, the mosque and annexes of the Sultan Ahmed complex, completed in 1617, was to be the last imperial project of its kind-the last great public monument in the tradition of the "Classical Age" to be offered for quite some time to the residents of Istanbul. As the sultan's extensive parades through the city grew more and more risky, this complex, which stretched from one end to the other of the Hippodrome's longer eastern side, came to occupy a central role in all state ceremonies. The ceremonial Friday processions, too, came to be limited to visits to the Sultanahmed mosque.

Simultaneously, there appeared signs that now, it was personal legitimation through messages of dynastic durability that sultans were beginning to crave above all. Apart from the overall atmosphere of crisis and uncertainty, they may have had other, more special reasons to do so. No fewer than six sultans who succeeded one another in the first half of the 17th century were either mentally disturbed, or else very young when they were enthroned. This both resulted from the general crisis (in the form of palace coups and depositions), and fed into it (in the form of a certain lack of authority). A shift from primogeniture to seniority was proceeding in tortuous, ambiguous fashion, shot through as it was with vestiges of earlier practices that kept re-surfacing. For example, Murad IV (r. 1623-1641), probably motivated by his own fears of being deposed amidst all this instability, had all his brothers except one murdered at various times, stopping only when nobody was left except the clearly demented İbrahim. Such conditions can only have further impressed the rest of the elite with the potential fragility of the royal line. In any case, it is interesting to note that Murad IV, like his immediate predecessors Ahmed I and Osman II, visited Bursa to pray at the tombs of the early Ottoman sultans. Ahmed I is also said to have stopped at Gelibolu to pay his respects to the remains of Süleyman Şah and other martyrs and gazis believed to have led the way across the Dardanelles in the early waves of Ottoman expansion into Rumelia. This was something of a new phenomenon; it seems to indicate that in troubled times, the sultans took special care to show themselves associating with their illustrious and long-deceased ancestors, thereby underlining the direct line of continuity, hence legitimacy, between them.

Only a few of the princesses born in the last quarter of the 16th century continued to be married off to top-ranking statesmen. These 
were the daughters of the future Selim II (r. 1566-1575) who were given away by their grandfather Süleyman I. Later, marriage alliances were rarely made during the reign of the brides' fathers; and if their arranged marriage happened to fall in the succeeding reigns of their uncles, brothers or nephews, many ended up taking as their husbands lesser officials or courtiers below the rank of pasha. ${ }^{16}$ Among Murad III's (r. 1575-1594) own daughters, said to have been more than thirty at the time of his death, only two were married off to topranking statesmen during the reign of their father. Many died during the small-pox epidemic of 1595, and the rest were married off by their nephew Ahmed I. ${ }^{17}$ Neither did Mehmed III (r. 1594-1603) take any steps towards marrying off his sisters or daughters. In fact, his own daughters are hardly ever mentioned by name in the chronicles or in any other kind of documentation. ${ }^{18}$

It seems that somewhere during or after the reign of Ahmed I (r. 1603-1617), the role ascribed to royal princesses began to change yet again. This, once more, was part of the impact of the general crisis on the dynasty, or of the interaction or overlap between a social and a dynastic crisis. At this time, there must have been an extremely high rate of attrition and turnover within the ruling elite, with most people teetering much more precariously than usual between enjoying sultanic (or grand vezirial) grace one day, and being handed over to the

16 The Veliyyüddin telhis, which Rhodes Murphey claims to be an antecedent of Koçi Bey's treatise, includes a note on suitable husbands that should be found for each of the Sultan's daughters. "What the author implies here," says Murphey, "is that while the sultanas remained at court they were both a burden on the treasury and liable to interfere in matters of state": Rhodes Murphey, "The Veliyyüddin telhis: Notes on the Sources and Interrelations between Koçi Bey and Contemporary Writers of Advice to Kings', Belleten XLIII, 171 (July 1979) p. 549. Murphey goes on to give a similar quote from Hirz al-Mulûk, written between 1575 and 1579, which in general condemns Sokollu's practices (fol. 12a), Murphey, 'The Veliyyüddin telhis', p. 559: "lâzim olan dahi budur ki eğer kerime-i mu'âzeme ve eğer hemşire-i mufahhereleridir, aslen ve kat'en vüzerâya ve beylerbeylerine tevzi' buyurulmayup dört yüz bin beş yüz akçe hasslar ile sancağa mutasarrif bir namdâr bey'e tevzi' buyurulup, onun dahi sancağı serhâdd'da olmayup iç-illerde olup ber vech-i te'bid mutesarrıf ola."

17 No other Ottoman sultan seems to have had as many children as Murad who is said to have over a hundred sons only. Naturally many died very young. In addition to the 31 little coffins located at the tomb of their grandfather Selim II, 25 more were to be found in a tomb made specially for his offsprings.

${ }^{18}$ In Mehmed III's reign, only one of his sisters, Ayşe, was married for the second time in April 1602; the marriage was consummated in February 1603: Uluçay, Padişahların Kadınları ve Kizları, p. 47. Alderson who does not give the names of his daughters records four husbands for Mehmed III's daughters: Anthony D. Alderson, The Structure of the Ottoman Dynasty (Oxford 1956) Table XXXIII. 
executioner the next. This was probably true of the more established members of the bureaucracy as well as of a host of newcomers. In the capital, factions kept rising and falling, regrouping and being crushed. Meanwhile, as previously explained, the Celâli uprisings sweeping the provinces, as well as the attempts to suppress them, were throwing up, in complicated ways, fresh groups of provincial magnates, commonly known as eşraf and $a^{c} y \hat{a} n$, who were constantly forcing their way or being coopted into the ranks of Ottoman officialdom. Like moths and flies flocking to the light only to be burned by it, they were engaging in a very dangerous game when they allowed themselves to be seduced by promises of wealth and rank into accepting an amnesty, coming to the capital, assuming some high post or command, and perhaps even marrying a royal princess. To many it may have seemed like a fulfillment of their wildest dreams, but frequently it amounted to nothing other than putting their heads in the lion's mouth.

Those jaws did close often enough, particularly if the would-be dignitaries in question were seen to be far removed from their power bases and therefore isolated and vulnerable. And every time they closed and opened, they could have released a freshly widowed royal princess to be re-married to yet another adventurous provincial arriving with the next wave from Anatolia in this meat-grinder of Istanbuliote politics, or else yet another middling courtier (an ăga or a kethudâ) hoping against hope to better his chances of survival by grasping, clasping at the skirts of the House of Osman. Hence this rash of royal women being married off to all-comers, with some of them going through as many as a dozen marriages. There could be no question here of a few select, carefully arranged alliances; instead, just short-run reflexes would have prevailed on all sides, allowing no more than a day-to-day groping for survival. There could be no question, either, of major wedding ceremonies, for nobody could afford to make any great investment in marriages fashioned one day and destroyed the next. One could say that the unpredictable fluidity and mediocrity of these marriages (as well as of the corresponding wedding ceremonies) had come to reflect the general chaos and mediocritisation of these unsettled times.

\section{Marriage Alliances and Ottoman Protocol from the Mid-17th Century Onwards}

By the mid-17th century, however, a somewhat different pattern was emerging as at least some princesses began to be given in marriage 
to their father's boon companions (musahib). ${ }^{19}$ This may have been a reflection of the sultans' search for ways to break out of their loneliness, and to find or create fresh networks of close, dependable circles around them. ${ }^{20}$ A new kind of court society appeared to be taking shape, one provisionally dominated not so much by autonomously established grandees making their regular way up the Ottoman bureaucracy, as by courtiers jostling around the sultan. This may also be why most princesses continued to get relatively minor courtiers as their husbands. Meanwhile, these early- or mid-17th-century sultans continued to shy away from public displays of imperial power. They included even Murad IV, who was relatively fortunate in having achieved a few military victories. All fell short of commissioning imperial mosque complexes or even Books of Kings (şahnâmes) in their own name-the two most outstanding symbols of personal rule. They also fell short of patronizing dynastic ceremonies, such as celebrations of royal births, circumcisions, or marriages.

At around this time, a drastic step was taken, probably by Köprülü Mehmed Pasha, in removing the very young Mehmed IV (r. 16481687) from the capital. Istanbul had become too unsafe under the double impact of internal sedition and the external menace posed by the Venetians blockading the Dardanelles (and even establishing themselves, albeit temporarily, on Limnos and Tenedos). ${ }^{21}$ Entrusted with extraordinary powers, the old grand vezir may also have wished to render the sultan inaccessible to any and all rival factions prior to cracking down on the latter. But in any case, by the second half of the 17 th century the court had settled in Edirne, which then functioned

19 This seems to have begun with Murad IV. He wanted to marry Kaya Sultan to his sword-bearer, Silâhdâr Mustafa Pasha, but upon the opposition of the Grand Vezir Kara Mustafa Pasha, Kaya was married to Melek Ahmed Pasha. It seems that it was the need to control and guide the mentally disordered İbrahim that led to the incorporation of those favourites who guarded him into the royal family. Thus all three surviving daughters were married to his boon-companions (musahib) when they were toddlers: Fatma's (b.1642) husbands were her father's best man (she was first married to Musahib Yusuf Pasha in 1645; and upon his death to Musahib Fazlı Pasha in 1646); Gevher(han) (b. 1642) was married to another favourite of İbrahim, Musahib Cafer Pasha in 1646); Beyhan (b. 1646) was married to then grand vezir Hazerpare Ahmed Pasha (1647) who, although, not a musahib at the time of the marriage, was certainly a favourite. See: Uluçay, Padişahların Kadınları ve Kızları, pp. 54-65.

${ }^{20}$ For similar needs (and more) see: J.H. Elliot and L.W.B. Brockliss, The World of the Favourite (New Haven; London 1999).

${ }^{21}$ Metin Kunt, The Köprülü Years: 1656-1661, unpub. PhD Diss., Princeton University (Princeton 1971) pp. 14-21. 
as the de facto seat of government for nearly half a century-without ever stripping Istanbul of its status and privileges as the official capital of the Ottoman empire.

During the long sojourn of the Ottoman court (and part of the state) in Edirne, the sultans seem to have taken a break not only from the military-charismatic mode of leadership of the 14th, 15th and 16th centuries, but also from assiduously cultivating the basic attributes or manifestations of the ideal of Islamic kingship, such as religiosity, justice, wisdom, permanence, devotion to learning, charity and benevolence. Instead, what we see is an emphasis on the continuity of the Ottoman dynasty. Thus Mehmed IV, following in the footsteps of Ahmed I and his direct successors (except for the mentally unfit Mustafa and İbrahim), chose Bursa as his destination on his very first trip out of Istanbul (and before he took up near-permanent residence in Edirne), during which he also made the same rounds of martyrs' and gazis' tombs at or near Gelibolu. ${ }^{22}$ This was not all, however. To this new mode of legitimation in the making, Mehmed IV added a few elements of his own, for example by using the opportunities provided by the military victories (achieved or expected) of his grand vezirs of the Köprülü family to commission both a novel genre of royal chronicle (vekâyi-nâme, commissioned in 1663 after the conquest of Uyvar), ${ }^{23}$ and a conforming dynastic genealogy (silsilenâme, commissioned on the eve of the Vienna campaign in 1683). ${ }^{24}$ The timing of the circumcision of his two sons, as well as the simultaneous marriage of his elder daughter to his boon companion (in 1675), captured for posterity in several sûrnâmes, ${ }^{25}$ roughly coincided with the military

\footnotetext{
${ }^{22}$ For tomb visits in the vicinity of Edirne: Fahri Çetin Derin, Abdurrahman Abdi Paşa Vekâyi'-nâme [Osmanlı Târihi (1648-1682) (İstanbul 2008) p. 139 (fol. 45a).

${ }^{23}$ For the development of the vekâyi'nâme genre: Rhodes Murphey, 'Ottoman Historical Writing in the Seventeenth Century: A Survey of the General Development of the Genre After the Reign of Sultan Ahmed I (1603-1617)', Archivium Ottomanicum XIII, Tibor Halasi-Kun Memorial Volume (1993-4) pp. 277-311. For the 1663 Austrian campaign, the conquest of Uyvar (13 September): Tarih-i Sultan Mehmed Han (Bin) İbrahim Han see: Topkapı Sarayı Müzesi Kütüphanesi R. 1308.

${ }^{24}$ Hans Georg Majer, 'Gold, Silber und Farbe. Musavvir Hüseyin, ein Meister der osmanischen Miniaturmalarei des späten 17. Jahrhunderts', in: Studies in Ottoman Social and Economic Life/Studien zu Wirtschaft und Gesellschaft im Osmanischen Reich, Proceedings of the VII. Internationaler Kongress für Osmanische Wirtschafts und Sozialgeschichte (1300-1920), Heidelberg, 25-29 July, 1995 (Heidelberg 1999) pp. $9-42$.

${ }_{25}$ Asl Göksel, The Surname of Abdi, unpub. MA Thesis, Bosphorus University (İstanbul 1983). For a treatment of the 1675 festival: Özdemir Nutku, IV. Mehmed'in Edirne Şenliği (Ankara 1987).
} 
triumph at Kamaniçe in 1672 . This also happened to be the campaign in which an Ottoman sultan took personal command of the army after a long interruption-and also the first and only campaign personally led by Mehmed IV. ${ }^{26}$ In 1676, a practical manual-called a law code (kânûnnâme) - setting out rules for promotions, and describing hierarchies and ranks for ceremonies ${ }^{27}$ was promulgated, followed in 1687 by a more extensive and elaborate code on all such administrative practices. $^{28}$

The authors of these works were experienced state officials. They took care to describe the state of affairs before Mehmed IV came to power, and thence to note the need to re-define state protocol. ${ }^{29} \mathrm{In}$ other words, Mehmed IV committed himself to a book of imperial festivities, a dynastic genealogy, and new codes of law-all of which were basic sources or emblems of legitimacy-only when he felt assured of the strength and durability of the House of Osman. ${ }^{30}$ In the meantime, the mundane doings of the sultan kept being chronicled, in yet another invention of tradition which was meant as an interim display of the sultanic presence. Altogether, while "a preoccupation with the health of the monarch and longevity of the dynasty was reflected in the tendency to provide detailed accounts of births, deaths, and marriages of persons related to the royal house" in Ottoman historical

${ }^{26}$ For an account of the campaign parade: Antoine Galland, İstanbul'a Ait Günlük Hatıralar (1672-1673), Charles Schefer, ed., Nahid Sırrı Örik, trans. (Ankara 1987 [1949]) vol. 1, pp. 114-130.

${ }_{27}$ Tevkîîi (Nişâncı) Abdurrahman Paşa, 'Osmanlı Kanunnameleri', Millî Tetebbu'lar Mecmû'ası 1, 3 (İstanbul 1331 [1916]) pp. 497-544.

${ }^{28}$ Hezarfen Hüseyin Efendi, Telhîsü'l-Beyân fî Kavânîn-i Âl-i Osman, Sevim İlgürel, ed. (Ankara 1998). It is mistakenly dated to 1675. Actually, the latest date recorded in the Telhisü'l-Beyân is 1686. Hezarfen correctly records the dismissal of Şeyhü'l-islâm Çatalcalı Ali Efendi on 27 September 1686 and names his successor Ankaravî Mehmed Emin Efendi as the final note on the section on the şeyhü'l-islâms. Mehmed Emin Efendi died on 2 November 1687 when he was still in office.

${ }_{29}$ The office of protocol started to function as a separate unit at around this time. Abdurrahman Pasha himself mentioned in several places the necessity and obligation for the state protocol that was forgotton in Mehmed IV's reign. Hezarfen, on the other hand, stressed his gentle criticisms here and there regarding the current sultan and his reign even more by devoting a large space to the circumcision of the two princes and the marriage of the two princesses towards the end of his manuscript. While the task was given to Abdurrahman Pasha by the grand vezir Mustafa Pasha, Hezarfen seems to have written his manuscript on his own initiative. It is possible that he received a commission, possibly from a foreigner-and most probably from Antoine Galland.

${ }^{30}$ Pal Fodor, 'Sultan, Imperial Council, Grand Vizier: Changes in the Ottoman Ruling Elite and the Formation of the Grand Vizieral Telhis', Acta Orientalia Academiae Scientiarum Hungaricae Tomus XLVII, 1-2 (1994) p. 70. 
writing, ${ }^{31}$ visits to ancestral tombs, participation in imperial campaigns, celebrations of dynastic rites of passages were also intended to convey broader messages about the enduring power and endurance of the House of Osman.

Mehmed IV was succeeded by two rather weary brothers both of whom reigned only briefly, but his elder son Mustafa II, who after a long wait finally took over in 1695 , was also keen to invest in public manifestations of dynastic permanence. Mustafa II seems to have been bent on formally re-instating Edirne as the capital and the abode of the imperial court. At the same time, he appears to have tried to reformulate the accession ceremonies of the sultanate. This is evidenced by the first Ottoman Book of Ceremonies that has come down to us, the Defter-i Teşrîfât of Mehmed bin Ahmed (Nî̀metî). ${ }^{32}$ Penned during the early years of Mustafa II's reign, it carefully distinguishes between the old and the new in this regard, including rites and ceremonies as they had been performed in İstanbul and were now to be performed in Edirne. Significantly, the master of protocol (teşrîfât tî or teşrîfâttçıbaşı) who authored this manual (and whose father Nî́metî Ahmed had served Mehmed IV in the same capacity for nearly three decades) attributes the search for both new designs and their conformity with kânûn-ı kadîm to the fertile mind of the sultan. Furthermore, the wedding ceremonies of royal princesses were now among the court rituals

\footnotetext{
${ }^{31}$ Murphey, 'Ottoman Historical Writing', p. 285. Contrary to Murphey's suggestion that all these features were found in Ottoman historical writing of all periods, the increase in detail and care to record the rites of passage of the royal women is striking especially towards the end of the 17th and throughout the 18th century.

32 (Teşrîfâtîzâde) Mehmed bin Ahmed Efendi, Defter-i Teşrîfat, Süleymaniye Library Es'ad Efendi no. 2150 (80 folios); İstanbul University Library TY. 9810 (128 folios). Uzunçarşılı made ample use of Nimetî (Ahmed) Efendi’s "Kânûnnâme" (which apparently was in his private collection) in his seminal survey of Ottoman statecraft: Uzunçarşıl, Merkez ve Bahriye Teşkilâtı. For Ottoman ceremonies and protocol also see: Tevkî̂î Abdurrahman Paşa, 'Kanunnâme-i Âl-i Osman'; Ali Seydi Bey, Teşrîfat ve Teşkilatımız (İstanbul n.d.); Es'ad Efendi, Osmanlılarda Töre ve Törenler (Teşrîfât-ı Kadîme) (İstanbul 1979); İsmail Hakkı Uzunçarșılı, 'Saltanat Şiarından Olan Bâzı Merasim ve Usul,' in: Osmanlı Devletinin Saray Teşkilatı (Ankara 1984 [1945]) pp. 184-224; Filiz Çalışkan/Karaca, Osmanlı Devleti'nde Teşrîfât Kalemi ve Teşrîfâttçllı, unpub. MA Thesis, IUÜ Sosyal Bilimler Enstitüsü (İstanbul 1989); eadem, 'Defter-i teşrîfât', TDV İslâm Ansiklopedisi IX (1994) p. 94; eadem, Tanzimat Dönemi ve Sonrasında Osmanlı Teşrîfat Müessesesi, unpub. PhD Diss., İÜ Sosyal Bilimler Enstitüsü (İstanbul 1997); Hakan T. Karateke, Das osmanische Hofzeremoniell im 19. Jahrhundert (Marburg 1998) translated Padişahım Çok Yaşa! Osmanlı Devletinin Son Yüzyllinda Merasimler (İstanbul 2004); idem, An Ottoman Protocol Register. Containing Ceremonies from 1736 to 1808: BEO Sadaret Defterleri 350 in Prime Ministry Ottoman State Archives, İstanbul (İstanbul; London 2007).
} 
described in detail by the master of protocol. This inclusion is remarkable also because Mustafa II is known to have acted quickly in assigning palaces, retinues and revenue sources to his numerous daughters born soon after his accession to the throne. ${ }^{33}$ At the same time, the sultan carefully arranged marriages for his infant daughters.

In the end, however, Mustafa II was not allowed to keep ruling in and from Edirne, and did not live to see his daughters' marriages. ${ }^{34} \mathrm{He}$ was forced to abdicate in 1703. His brother Ahmed III was enthroned and taken back to İstanbul only after he promised that he would reside there permanently and not try to leave for the provinces. Ensconced once more in the urban matrix of Istanbul, Ahmed III and his immediate successors set about reconstructing dynastic legitimation in the capital. This was the moment when the sultan turned yet again to the female members of the imperial family, and began to arrange marriages between his daughters (or daughters of Mustafa II) and promising members of his new court. Another pattern thus appeared, which was both old and new. After a hiatus of a century or so, once more there were repeated marriage celebrations that enlivened the capital. On the one hand, the sultan delegated power to princesses as partners in enhancing the dynasty's public profile. On the other hand, they for their part imparted a novel identity to a set of symbolic rituals in which they had been major actors only in the distant past. All this was in full conformity with the re-inscription of the court and the dynasty into the capital, and the re-legitimation of the post- 1703 sultanate in the wake of resettling in Istanbul.

\section{Reflections of a Festive Court in Early-18th Century İstanbul}

The 1724 processions were not a unique occasion. Instead, they constituted only one link, albeit a very important one, in a series of imperial

\footnotetext{
${ }^{33}$ Among the reasons for the disturbances that culminated in the 1703 upheaval, contemporary chroniclers like Fındıklılı Mehmed Ağa and Defterdâr Sarı Mehmed Pasha refer to the two palaces of equal size and splendour, modeled on the Old Palace in Istanbul, which were under construction for Ayşe and Safiye. Taken as an indication of the court's moving to Edirne, the rumour that the personnel of the Old Palace were going to be moved to these two palaces had caused considerable unrest in İstanbul. Mustafa II was dethroned in 1703 and the collective marriage ceremony that he was anticipating was cancelled.

${ }^{34}$ Rifa'at Ali Abou el-Haj, The 1703 Rebellion and the Structure of Ottoman Politics (İstanbul 1984).
} 
projects that were designed in the reign of Ahmed III to engender fresh images of dynastic power and permanence. As part of a subordinate enterprise of massively upgrading royal weddings and reinstating them as ceremonies at least partially accessible to the general public, there were several major royal weddings that were organised in the first quarter of the 18th century. Four princesses were married off by the sultan between 1708 and 1710. One was Ahmed III's firstborn, Fatma Sultan, and three were his then-deceased brother and predecessor Mustafa II's (r. 1695-1703) daughters who had already been betrothed during their father's reign. After an interval of ten years, nine more princesses were married off in triple ceremonies in 1720 , 1724, and 1728, including daughters of both Ahmed III and Mustafa II. There were numerous other royal marriages in this period which were neither lumped together nor celebrated with pomp and display. On the contrary, these were rather private, silent and humble observances. It appears that in all such cases it was the second, third or fourth marriages of the princesses in question. ${ }^{35}$

So the 1724 weddings did not stand alone. At the same time, it would be naive to claim that this entire course of events had already been charted back in 1703-08, or that there was a single blueprint adopted right from the outset which kept being repeated. Rather, we see Ahmed III and his counselors (including of course the key figure of Nevşehirli Damad İbrahim Pasha) nurturing a basic notion of what they wanted to do (probably in terms not far from those that I have used, i.e. offering grandiose ceremonies and spectacles to the public, and needing to upgrade royal weddings, too, to that end), and then groping their way towards their objective partly in a trial-and-error kind of way, and partly by studying the dynasty's past (but not entirely forgotten) rites of power. In other words, while embarking on projects aiming to bring back the grandeur of the capital, the sultan and his aides not only launched designs to empower the city with a new urban scheme and architecture, but also took a keen interest in the implantation of stately urban rituals, new processional routes, new festival

${ }^{35}$ Among those who were married in the same period for the second and third, even fourth times were Mustafa II's daughters: Emine marrying to Receb Pasha in 1712, İbrahim Pasha in 1724 and Abdullah Pasha in 1728; Ayșe marrying to Tezkereci İbrahim Pasha in 1720 and Koca Mustafa Pasha in 1725; and Safiye marrying to Mirzazâde Mehmed Pasha in 1726. 
grounds, and new ceremonial procedures. They were also becoming absorbed in recording such events.

The numerous sûrnâmes of this period had yet another function. In sharp contrast to the late-17th-century attempts to re-formulate the state protocol and ceremonies (in Edirne), witnessed by the treatises of Hezarfen Hüseyin Efendi, Abdurrahman Pasha, and Mehmed bin Ahmed (Nî́metî), the reign of Ahmed appears at first sight to have lacked a new book of protocol or ceremonies. ${ }^{36}$ However, the surviving sûrnâmes of the $1708,1709,1710$ and 1724 royal weddings did serve that purpose. The last named, replete with detailed codes of ceremonial attire and trappings, reflects not only a collective effort but also the personal initiative of Damad İbrahim Pasha. That they were trying out new strategies and also adapting to new circumstances is evident from the differences between the 1724 processions and those of 1708 , 1709 and 1710.

The Vienna sûrnâme requires an explanation vis-à-vis its dating. At the very beginning of the account, the main actors, including Ahmed III (d. 1736), Ümmügülsüm (d. 1732), Ali Pasha (d. 1732), Hadice (d. 1738), Ahmed Pasha (d. 1735), 'Atîke (d. 1737) are all referred to as deceased. Only Mehmed Pasha (d. 1768) was alive when the 1724 weddings were recorded. It seems that the Vienna sûrnâme, written in fine riqa script, was re-copied sometime in Mahmud I's reign, perhaps in preparation for the official chronicles of Mehmed Râşid/Küçük Çelebizâde and Subhî. Not only the quality of the manuscript, but also the fact that the text has no repeat reference to the main characters as deceased, suggests that the Vienna copy was a later rendering intended as a book of protocol.

\section{The (Re)invention of a Tradition}

In April 1708, the late Mustafa II's elder daughter Emine (born in 1696) was given in marriage to the then-grand vezir Çorlulu Ali Pasha. Emine had been betrothed to Ali when he was her father's

${ }^{36}$ A new Code of Law that is incorrectly attributed to the reign of Ahmed III is devoted solely to the issues of administration of land tenures. It is more likely to have been put together in the reign of Osman II, and copied both in 1706-7, and in 1798: Oğuz Ergene, III. Ahmet Dönemi Osmanlı Kanunnamesi (İnceleme, Meting, Dizin), unpub. MA Thesis, Mersin Üniversitesi (Mersin 1997). 
sword-bearer. ${ }^{37} \mathrm{~A}$ month after this sumptuous wedding, in May 1708, another daughter of Mustafa II, Ayşe Sultan (also born in 1696), was married to Fazll Mustafa's son Köprülüzâde Numan Pasha, then the governor of Belgrade, to whom she had remained betrothed since she was seven. In the first case, both Emine's trousseau and her marriage procession-i.e. two of the three key pageants-headed for the grand vezir's palace which was just across the road from the Kiosk of Processions (Alay Köşü), a pavilion incorporated into the outside wall of the Topkapı Palace during the reign of Murad III (1574-1595) where sultans came to watch and enjoy parades. Both processions, led by top dignitaries, left from the Imperial Gate, passing by the Cebehâne (the Church of St Irene), the Bath of Ayasofya, and through the street called Soğukçeşme to reach the grand vezir's palace. It was quite a short and direct route for such sumptuous parades. ${ }^{38} \mathrm{~A}$ month later, after sending on her trousseau, Ayşe and her equally magnificent procession left for the Zeyrek palace that had been allocated to her. But instead of accompanying Ayşe Sultan all the way to Zeyrek, a neighbourhood to the northwest of the Valens Aqueduct, it seems that in this case, too, the dignitaries went only as far as the grand vezir's palace. From this point onwards, the more functional core of the procession, comprising the princess and her trousseau, was taken to the Zeyrek palace in a relatively quiet and unostentatious way. ${ }^{39}$

Ahmed III seems to have been quite taken with the splendour of the collective wedding of his two nieces. Next year, in May 1709, the sultan engaged his two year-old Ümmügülsüm to the vezir Abdurrahman Pasha, a loyal follower of the Köprülü family, ${ }^{40}$ and also married his

37 When Emine was five she was engaged to the governor of Damascus (Emîr-i Hac) Hasan Pasha: Defterdâr Sarı Mehmed Paşa, Zübde-i Vekâyiât. Tahlil ve Metin (10661116-1656-1704), Abdülkadir Özcan, ed. (Ankara 1995) p. 724. This engagement was anulled in 1701 and the same year she was engaged to (then Silâhdâr) Çorlulu Ali: Mehmed Râşid, Tarih-i Râşid II, p. 529.

${ }_{38}$ For the sûrnâme and a document recording the gifts see: TSM Library H. 1573/2 (late 18th century?) and TSM Archives, E. 962, respectively: Mehmet Arslan, 'II. Mustafa'nın Kızları Ayşe Sultan ve Emine Sultan'ın Düğünleri Üzerine Bir Belge', Revak Dergisi (Sivas 1996) pp. 60-70. See also: Mehmed Râşid, Tarih-i Râşid III, pp. 243-245; Silâhdâr Findıklılı Mehmed Ağa, Nusretnâme II/II, İsmet Parmaksızoğlu ed. (İstanbul 1962) pp. 243-244; Uşşâkizâde es-Seyyid İbrâhîm Hasîb Efendi, Uşşâkî̀zâde Tarihi, Raşit Gündoğdu, ed. (İstanbul 2005) pp. 940-943; M. Çağatay Uluçay, Harem II (Ankara 1985) p. 100, Uluçay, Padişahların Kadınları ve Kızları, p. 76.

39 Mehmed Râşid, Tarih-i Râşid III, pp. 243-245.

40 Abdurrahman Pasha was the steward of Köprülüzâde Numan Pasha. He probably fell out of favour when Numan Pasha was dismissed from the grand vezirate in 1710 . 
four-year-old daughter Fatma to his own sword-bearer, the upwardly mobile Silâhdâr Ali Pasha. Once more the ceremony was exciting and engaging for İstanbuliotes. They first watched the transfer of Fatma's trousseau. Then, while the infant Ümmügülsüm stayed with her family, the child bride Fatma was formally taken to the waterfront palace of her grandmother at Bahariye (Valide Yalisl), further down from Eyüb, at the far end of the Golden Horn. The procession, again led by top dignitaries, left the Imperial Gate, passed through Soğukçeşme, and under the Alay Köşü̈, arrived outside the gate of the grand vezir's palace, turned and went uphill to Dîvânyolu (the Byzantine Mese). It then proceeded along this ceremonial route to reach Saraçhâne by way of Vezneciler, passed by the medrese of (Fatih) Sultan Mehmed and the Büyük Karaman Çarşusu, marched through Edirnekapı, went all the way through Otakçllar, and reached the Valide Yalısı. In a minor mishap, a group of attendants from the naval arsenal carrying nahils, that is to say, symbols of fertility and good fortune in the form of sugar gardens, could not make it through narrow streets as part of the procession. They stopped in the vicinity of the Şengül Hamamı (next to the grand vezir's palace), and brought the nahils after the evening prayers, probably by another route. ${ }^{41}$

Exactly a year later, in May 1710, it was the turn of Safiye Sultan, the third daughter of Mustafa II (also born in 1696), to be married. Betrothed at the same time as her sisters Emine and Ayşe, she had been waiting for her turn since 1703, and her fiancé was the son of Merzifonlu Kara Mustafa Pasha, known as Maktûlzâde Ali Pasha, and the governor of Adana at the time. This procession traveled only a short distance from the Imperial Gate (via Cebehâne and Soğukçeşme) to the princess's palace at Demirkap1, known as "Râmi Pasha's palace", where the marriage was consummated-despite the fact that the bridegroom still had several palaces of his own which he had inherited from his disgraced father. ${ }^{42}$ Soon afterwards, in June 1710 , the bridegroom

Abdullah Pasha then served as the chief treasurer (defterdâr) in the retinue of yet another Köprülü descendant, Abdullah Pasha, who was the second son of Köprülü Mehmed Pasha.

${ }^{41}$ TSM Archives D. 10590 (23 S 1121). Uşşâkizâde, Uş̧̧âkîzâde Tarihi, pp. 962, 972-4. See also: M. Çağatay Uluçay, 'Fatma ve Safiye Sultanların Dügünlerine Ait Bir Araştırma'; Mehmet Arslan, 'III. Ahmed'in Kızı Fatma Sultan'ın Düğünü Üzerine Önemli Bir Belge', Yedi İklim Dergisi 34 (1993) pp. 66-74.

${ }^{42}$ TSM Archives D. 10591 (2 RA 1122). See: Mehmet Arslan, 'II. Mustafa'nın Kızı Safiye Sultan'ın Dügünü Üzerine Önemli Bir Belge', Kızılırmak Dergisi 8 (1992) pp. 15-22. 
was sent away to Diyarbekir as provincial governor, and almost never made it back to İstanbul. The grand vezir himself was dismissed on 16 June, and Köprülüzâde Numan Pasha followed him into office.

Here we come up against an interesting problem with regard to building power bases, close circles, and extended households. At first glance it seems that at least in 1708, 1709 and 1710, the husbands chosen for Sultan Mustafa II's daughters were more established personages at the time of marriage when compared with the husbands Ahmed III was picking for some of his own daughters. At betrothal time, however, Çorlulu Ali, too, had been no more than Mustafa II's sword-bearer (and had therefore been known as Silâhdâr Ali Ağa), but both Köprülüzâde Numan and Maktûlzâde Ali had already risen to become governors thanks to their Köprülü connections. As we shall see, in the course of the 18th century it would become increasingly common for a sultan to select his sword-bearer as (one of) his future son(s)-in-law, whereas it was much more exceptional for royal princesses to be engaged to established pashas (such as grand vezirs or grand admirals). Indeed it was Çorlulu himself who was instrumental in elevating the post of sword-bearer. ${ }^{43}$ Beyond their rank, what was common to Numan and Ali was that they both belonged to the Köprülü family. In arranging for them to eventually marry two of his daughters, Mustafa II may well have been looking to bond with this powerful clan (which his father Mehmed IV seems to have neglected). ${ }^{44}$ Mustafa II appears to have made his choice against many Köprülü opponents among his statesmen.

At the same time it becomes important to note that Ahmed III abided by his brother's wishes, though this was not automatic: as reigning sultan he could well have replaced existing arrangements with others. On the other hand, he may have preferred not antagonizing his late brother's household and inner circle, at least when his own was still in the making (in 1708-10). Nevertheless, he seems to have taken certain measures to keep the former in their place, and perhaps to indicate to them that this was no longer their day. Thus while (his now grand vezir) Çorlulu Ali’s marriage was sumptuous, Köprülüzâde

\footnotetext{
${ }^{43}$ M. Aktepe, "Çorlulu Ali Paşa," TDV İslâm Ansiklopedisi VIII (İstanbul 1993) pp. $370-71$.

${ }^{44}$ Indeed Mehmed IV gave his infant daughter Emetullah (Ümmî), known as Küçük Sultan, to Merzifonlu Kara Mustafa Pasha in 1675: Derin, Abdurrahman Abdi Paşa Vekâyi '-nâme, pp. 443-444 (fols.134a-135b).
} 
Numan's was very modest; and Maktûlzâde Ali was not even permitted to take his royal bride to a palace he had inherited from his father. On closer examination, it also becomes clear that while it was usual for royal bridegrooms to move back and forth between the provinces and the capital, Numan and Maktûlzâde Ali (as well as the rest of the surviving members of the Köprülü family) were always kept away from the capital. Furthermore, these royal in-laws who were descendants of the later Köprülü grand vezirs, and who had once been loyal to Mustafa II, were not going to survive for long. Eventually Ahmed would be bringing in his own men both as royal grooms and topranking bureaucrats. Later, indeed, Ahmed III did move, carefully and strongly, to set up his own household and power clientele by marrying his nieces (for a second and even a third time) as well as his own daughters to his own supporters in positions of power and influence. So the story of Mustafa II's daughters' marriages embodies not only a shift from one royal household to another, but also a parallel subplot of the rise and then fall of a secondary but still very powerful military-bureaucratic dynasty. It reveals how the half-century sway of the Köprülüs was brought to an end as Ahmed III consolidated his own networks of power.

\section{Royal Marriages as Part of Damad İbrahim Pasha's Ruling Strategies}

Only after he found himself a strong and staunch ally in the person of İbrahim Pasha, did Ahmed III move in more open and determined fashion to re-inscribe his House and himself into the capital. Nevşehirli became "Damad", the Royal Bridegroom, by marrying Fatma Sultan on 19 February 1717, and took over as grand vezir on 9 May 1718, that is to say just over a year later. From then on, a succession of royal betrothals and weddings began in real earnest, so much so that within Ottoman history as a whole, it is the latter part of Ahmed's reign which truly stands out in this regard. Furthermore, this went hand in hand with a massive investment in architectural patronage in the capital. The weddings and palaces reserved for princesses in the historical peninsula became the last word in pomp and circumstance. The value of all gifts given and received, the way they were presented, the festivities running through each wedding-in short, all that was expected from such a union-came to be regarded as extremely important, indeed essential for both parties. 
Last but not least, while we have to rely on only a few sources for our understanding of pre- or early-18th-century royal weddings, for the festivities of 1720,1724 and 1728 there is much more ample documentation, which also casts light on the underlying motivations and thought processes. For now, behind these last three collective marriages, one can discern the strong planning, designing, staging hand of none other than Damad İbrahim Pasha whose own marriage to Fatma, the widow of Silâhdâr/Şehid Ali Pasha, had not been celebrated extensively because it was the princess's second marriage.

\section{Collective Marriage I (1720)}

The marriage ceremonies that preceded the circumcision of Ahmed III's four sons, united two daughters of Sultan Mustafa II with two senior statesmen. (1) Ayşe, whom we have already met, and who had been married to Köprülüzâde Numan Pasha (in 1708), was now given in her second marriage to Silâhdâr İbrahim Pasha, previously a sword-bearer of Ahmed II, while (2) Emetullah was given in her first marriage to Osman Pasha. Known by at least four different nicknames-Silâhdâr, Çerkes, Küçük, Sinek - this Osman Pasha had also risen from serving as a sword-bearer to Mustafa II, and had been previously married to Rukiye, a daughter of Fatma Sultan, who in turn was a younger sister of the royal brothers Mustafa II and Ahmed III. Both bridegrooms are known to have brought valuable gifts to members of the royal family, and these gifts were immediately transferred to the Imperial Treasury.

However, once again their marriages were given only passing mention in period chronicles, European mémoires, and two sûrnâmes which otherwise record the circumcision festivities in minute detail. ${ }^{45}$ Such was the relative silence surrounding the princesses' marriages, that it gave rise to some confusion regarding their identities. Thus even Sûrnâme-i Vehbi, the official account of the whole event, probably goes astray in identifying the royal wife of ex-Silâhdâr İbrahim not as Ayşe but as Emine Sultan. But tellingly, it also notes that the whole arrangement was kept secret, and that there were "various rumours" at the

${ }^{45}$ Mehmed Râşid, Tarih-i Râşid V, pp. 214-272; Schefer, Mémoire historique, pp. 38, 40, 70, 142 . 
time ${ }^{46}$ Although it was Ayşe's (and it would also have been Emine's) second marriage, Emetullah was a virgin bride. It might have been Osman Pasha's earlier royal marriage (to Rukiye) that led to the relative discounting of Emetullah's marriage alongside her elder sister's.

\section{Collective Marriage II (1724)}

Four years later, in 1724, the marriage ceremony that was carefully designed to impress the capital was also orchestrated by Damad İbrahim Pasha, who happened to be marrying his own son (from an earlier marriage) as well as his nephew to two of Ahmed III's daughters. ${ }^{47}$ Also under his patronage, an outstanding statesman with an illustrious pedigree was getting married to yet another daughter of the sultan. The sûrnâme that was written for this collective wedding ceremony in 1724 after the death of Ahmed III was, as already indicated, a rare record which seems to have doubled as a register of protocol.

\section{Collective Marriage III (1728)}

Before embarking on the exploration of the 1724 festivities, it is necessary to note that in 1728 , there took place the third and last collective marriage of Ahmed III's reign. All the princesses in question were daughters of the reigning sultan who were getting married for the first time: Ayşe (1719-1775) to Silâhdâr (Istanbullu) (Kunduracizâde) Mehmed Pasha; Saliha (1715-1778) to Sarı Mustafa Pasha, then commander of Revan (and son of Deli Hüseyin Pasha); and Zeynep (?-1774) to yet another nephew of the grand vezir, (Küçük) Sinek Mustafa Pasha, the second head of the royal stables (mîrâhûr-l sagìr) at the time.$^{48}$ In the aftermath of the 1730 rebellion which cost the grand vezir's life and terminated the reign of Ahmed III, not only did

${ }^{46}$ Tulum, 'Çeviri Yazılı Metin', p. 218 (32a); Mübeccel Kızıltan, The "Sûrnâme” of Mehmed Hazin As a Sample of Old Turkish Prose, unpub. MA Thesis, Bosphorus University (İstanbul 1987). The confusion is reflected in the secondary sources. Mehmed Süreyya says that Osman Pasha was married to Emetullah in 1694: Mehmed Süreyya, Sicill-i Osmanî 4, p. 1307.

${ }_{47}$ Tülay Artan, 'Yönetici Elitin Saltanatın Meșruiyet Arayışına Katılımı', Toplum ve Bilim 83 (Osmanlı: Muktedirler ve Mâdunlar) (Winter 1999/2000) pp. 292-322.

${ }_{48}$ The three princesses were settled at Valide Sultan Kethüdası Mehmed Pasha's palace at Süleymaniye; at the Defterdâr İskelesi Palace at Eyüb; and at the Kıbleli Palace at Ayasofya respectively. 
collective marriages come to an end, but occasions for festive urban celebrations also became much more rare in general. ${ }^{49}$

\section{The 1724 Wedding Processions: The Court and the City}

I shall now turn to the Vienna sûrnâme, which, I am convinced, indicates that it was in 1724 that the route and routines utilized in 1708-1709-1710 (and possibly 1720) were reformulated so as to further highlight and glorify Damad İbrahim Pasha, his family, and his household.

What is immediately striking about the anonymous sûrnâme in the Vienna Nationalbibliothek is its extremely detailed account of the various 1724 processions. ${ }^{50}$ As such it differs from accounts of the 1708 , 1709 and 1710 celebrations, which were actually written in the 1740s. In fact, it could be that these other accounts, too, were ordered to be penned a posteriori in a way that was intended either to help with Nevşehirli's re-designing effort and/or to mark the differences between the three earlier festivals and the grand vezir's stipulations for 1724 .

While Küçük Çelebizâde İsmâil Âsım Efendi's addendum to Tarihi Râşid, covering October 1722-July 1729, also provides an account of the events of $1724,{ }^{51}$ it is the sûrnâme in question that is the most extensive. Included are marching orders for all the top dignitaries, secondary officials, guards and servants that participated in each procession, as well as the descriptions of the head-gear and costume that each statesman, functionary and attendant wore on these occasions.

49 The only account of the 1728 marriage has been located in Küçük Çelebizâde: On 25 May 1728 (15 L 1140), the bridal gifts were sent by the procession designed in 1724, in the company of Tevkîi î Ali Pasha, the best men and the proxy of the bride, and the grand vezir's steward Mehmed Pasha. Two days later, trousseau of Saliha Sultân was transferred to her palace at the Defterdâr İskelesi at Eyüb. The next day, following the wedding ceremony, the princess left from the Bâğçekapı and was taken to her palace via the road outside the city walls with the established procession which took two hours: On 18 November (15 R 1140), wedding ceremonies of Ayşe and Zeynep took place at the Topkapı Palace, in the way they were accounted in earlier ceremonies. Five days later, Ayşe Sultân's trousseau was sent to her palace. Then, on 8 December (6 CA 1140) Zeynep's trousseau was sent and the next day the wedding procession took place. The only other collective marriage that was celebrated later in the 18th century was in 1740 .

${ }^{50}$ Karateke noted that Vienna National Library obtained three protocol registers through Hammer-Purgstall: Karateke, Ottoman Protocol Register, p. 38, n. 122.

${ }^{51}$ Mehmed Râşid, Tarih-i Râşid V, pp. 90-101. 
There is even a systematic account of their horse trappings. It is this level of detailed description that imparts something of the nature of a book of ceremonies to this sûrnâme. Thus while it is very similar to the aforementioned 1695 Defter-i Teşrîfât of Mehmed bin Ahmed (Ni'metî) in paying special attention to head-gears and costumes, it is strikingly different from earlier sûrnâmes which are not at all concerned about dress codes and horse trappings. What is also different in the 1724 sûrnâme is the recording of the exact route that the processions took in each specific case, perhaps another indication that the event was both new and important. ${ }^{52}$ The ancient Hippodrome, long distinguished as the monumental core of the city where imperial and dynastic rites were observed, was now (once again) being ceremonially connected to the grand vezir's palace.

The 1724 sûrnâme displays virtually a modern flavor in its level of exactitude-something that would appear to have been demanded. Of a total of nine imperial parades, namely three each of alay-ı nişân, alay-ı cihâz, and alay-ı arûs, the following were minutely recorded:

Alay-ı Nişân (of Ümmügülsüm and 'Atîke [and Hadice]): ${ }^{53}$ On 20 February 1724 (25 CA 1136), the betrothal gifts presented by the two bridegrooms (Ali and Mehmed) were transported from the palace of the grand vezir to the Imperial Palace. ${ }^{54}$ While the first file of gifts is

52 The accounts of the marriages of Emine and Ayșe, Fatma, and Safiye preserved in TSM Archives, H. 1573/2, D. 10590 and D. 10591, are the closest examples in this genre. However, they list only the titles of the statesmen, functionaries and attendants but do not include the ceremonial attires and their horses' trappings which are crucial in the delineation of hierarchy and rank. Küçük Çelebizâde Âsım Efendi on the other hand, did record the ceremonial attire and the trapping of those dignitaries who were going to be part of these processions for the first time.

${ }_{53}$ Codex Vindobonensis Palatinus $\mathrm{OH}$ 95: for the preparations:, 65a-65b; procession: $66 \mathrm{a}-67 \mathrm{~b}$; marriage ceremonies: $67 \mathrm{~b}-70 \mathrm{~b}$.

${ }^{54}$ A day earlier, the grand vezir Damad İbrahim Pasha's palace and the Imperial Council Hall (Divanhâne/Kubbealtı) were decorated in the manner very similar to the embellishments during the religious festivals, with luxurious cushions, pillows and Persian rugs. The sultan's seat was facing the entrance of the Dîvânhâne. Offices of the government were also furnished (by the mehterhâne). Again, just a day before the ceremony, the betrothal gifts (of Ali Pasha and Mehmed Pasha, the grand vezir's nephew and son) were put on display at the grand vezir's palace. On the day of the engagement the grand admiral was assigned as the best man of Ali Pasha and the Kethudâ Beg became the proxy and best man of Ahmed Pasha and Mehmed Pasha. There were two witnesses for each couple. These were, for all the three princesses, the treasurer and the boon-companion of the sultan. The two witnesses representing Ali Pasha were his steward and a senior officer of his household council (dîvân efendisi); and, for Ahmed Pasha, too, the witnesses were his steward and a representative of his household (ademîsi), possibly also his dîvân efendisi. Mehmed Pasha, the grand 
given in detail, the second, which immediately followed, is only noted as conforming to the same order. Furthermore, although all three marriage contracts were concluded the same day, there is no mention of Hafız Ahmed Pasha's betrothal gifts. Apparently Hafız Ahmed had not yet arrived from Sayda, so that his marriage to Hadice was formalised in the presence of his proxy. His betrothal gifts were either not paraded that day, or else the procession was not mentioned in the sûrnâme because-as was also the case with Mehmed-it entailed nothing but a repetition of the procession for Ali's gifts. In any case, Hafiz Ahmed Pasha arrived four days later. That they could not wait even for a few days for his arrival suggests that the final schedule was taken very seriously. [Appendix I]

Alay-ı Cihâz of Ümmügülsüm: ${ }^{55}$ On 28 February 1724 (3 C 1136), the trousseau of the princess was taken from the Topkapi Palace to her palace at Kadırga Limanı in no fewer than eleven carriages (kapaklı araba). [Appendix II)

Alay-ı Arûs of Ümmügülsüm::5 Then, on 2 March 1724 (6 C 1136), which was a Thursday, the princess was taken from the Topkapi Palace and transported to the Kadırga Palace. [Appendix III]

Alay-ı Arûs of Hadice: $:^{57}$ On 6 March 1724 (10 C 1136), it was the turn of the trousseau of Hadice Sultan to be transported from the Topkapı Palace via Ahırkapı Yolu to the Kibleli Palace that had been assigned to her. Then on the 9th (13 C 1136), which also happened to be a Thursday, the princess herself was taken to her palace.

Alay-ı Arûs of 'Atîke: ${ }^{58}$ Ten days later, that is to say on 13 March, 'Atîke's trousseau, and on 16 March 1724 (17 and 20 C 1136), 'Atîke Sultan herself were transported from the Topkapı Palace to her palace at Cağaloğlu.

The Vienna sûrnâme thus lists a nişân (for both pashas), a cihâz, and three arûs processions. The missing accounts are the nişân procession

vezir's son, however, was represented by the Re'is Efendi and the Çavuşbaşı, the two high-ranking state officials, members of the Imperial Council.

${ }_{55}$ Codex Vindobonensis Palatinus $\mathrm{OH}$ 95: for the procession: 71a-73a; gifts: 73b-74a.

${ }^{56}$ Codex Vindobonensis Palatinus $\mathrm{OH}$ 95: for the preparations: 74a; procession: 74b-77b; gifts of the bridegroom: 78a.

${ }^{57}$ Codex Vindobonensis Palatinus $\mathrm{OH}$ 95: for the procession: 82b-83b; celebrations: $83 \mathrm{~b}-84 \mathrm{a}$.

${ }^{58}$ Codex Vindobonensis Palatinus $\mathrm{OH}$ 95: for the procession: $84 \mathrm{~b}-85 \mathrm{a}$; gifts: $85 a-86 a$. 
for Hadice and the cihâz processions of both Hadice and 'Atîke. Strikingly, Küçük Çelebizâde chose to include exactly the same events in his chronicle. Indeed the order of parade for the grandees (alay-ı ricâl) is also not repeated for each procession, but briefly referred to as "with the procession organized formerly for Ümmügülsüm Sultan (mukaddema Ümmügülsüm Sultan hazretleri için tertib olunan alay ile)".

In other words, what we have is one complete set, recording the three separate processions for the marriage of Ali Pasha and Ümmügülsüm, reflecting on the identities of the participants, ranks and hierarchy, ceremonial costumes and head-gears, horse trappings, gifts and palace rituals. ${ }^{59}$ The rest is there in a shorthand format. Furthermore, it seems that the transfer of all three brides is included only to describe the different routes leading to the palaces of the princesses in different quarters of the historical peninsula. To be more specific, the accounts of Hadice's and 'Atîke's wedding parades appear to draw attention to the center of gravity, the Hippodrome. For regardless of where the assigned palaces might lie, all such processions had to go through the Imperial Gate, pass below the Alay Köşkü for acclamation (alkış), stop before the gate of the grand vezir's palace, move on to Dîvânyolu, ${ }^{60}$ and then enter the Hippodrome/Atmeydani. They even had to go around the Hippodrome a second time before they went their different ways.

${ }^{59}$ For the identification of ranks and hierarchy in the first quarter of 18th century I relied primarily on Hezarfen Hüseyin Efendi and Abdurrahman Abdi Pasha's manuals which were both written in the last quarter of the 17th century when the court was residing in Edirne. Despite their obvious limitations, both Uzunçarşıll and Gibb and Bowen, are also still helpful. While the first introduces a variety of sources on the structure of the Ottoman court and administration, the most significant for our purposes being the Nimetî Ahmed Efendi Teşrîfatnamesi (which was in Uzunçarşıllı's private collection), the latter makes a full use of a late-18th-century source, that of Mouragea D’Ohsson's Tableau Générale de l'Empire Ottoman, and several mid-19thcentury sources such as the chronicles of Ahmed Cevded Pasha and Tayyârzâde Atâ and Mustafa Nurî Pasha's Netâ'icü'l-vukû̀ât.

${ }^{60}$ Dîvânyolu, the major thoroughfare in the historical peninsula that joined the Topkapi Palace to the Beyazid square via Sultanahmed square, was the Byzantian Mese, the imperial route which joined the Augusteion to the Filadelfion. It does not really correspond to Dîvânyolu today and this is attested to even by some early-19thcentury maps if not by numerous narrative sources. For comparison see: Maurice Cerasi, The Istanbul Divanyolu. A Case Study in Ottoman Urbanity and Architecture (Würzburg 2004). 


\section{Ottoman Processions in a Broader Context: Atmeydani at the Center,} the Grand Vezir as the Core

There are several differences between the processions of 1708, 1709, 1710 and 1720, and what happened in 1724. (Discrepancies with the 1675 Edirne processions are even more remarkable, but this is beyond the limits of this study.) First, the nişân processions in the 1708, 1709, and 1710 weddings were not spectacular pageants-betrothal gifts were taken to the imperial palace in a rather private and subdued way. ${ }^{61}$ The starting point of the processions was always the Sublime Porte-the grand vezirial palace. As for the royal weddings of 1720 , they were hushed-up in a more comprehensive way. In contrast, in 1724, the parade of betrothral gifts leaving the grand vezir's palace was certainly designed to help enhance the public understanding that the royal bridegrooms were Damad İbrahim Pasha's relatives and accomplices. The gifts themselves were richer and more varied. Also, the symbolic items that were ritually displayed in earlier engagement ceremonies differed considerably from those that were publicly paraded in 1724 .

Second, the valide sultan played an obviously crucial role in the three earlier ceremonies. ${ }^{62}$ She was Emetullah Gülnûş (wife of Mehmed IV), and quite possibly she had been instrumental in arranging the marriages of Mustafa II's daughters to the descendants of the Köprülüs.

${ }^{61}$ The gifts of Çorlulu Ali Pasha (and that of Numan Pasha) were modest. The gifts that were prepared and kept at the palace of the grand vezir were transferred to the Imperial Palace by guards carrying trays on their heads. The gifts of Silâhdâr Ali Pasha, more sumptuous than those of Ali and Numan, were kept at the Sofa Köşkü. The grand admiral who was assigned as the best man of the bridegroom, the bridegroom himself, the steward of the grand vezir, and the steward of the bridegroom arrived at the Sofa Köşü rather silently by way of the Imperial Gardens. Then they accompanied the gifts, nahils, sugar gardens and various other ritualistic items that were transported from the Sofa Köşü, via the Imperial Gardens, through the Demirkapı, passed by the grand vezir's palace, and reentered the Imperial Palace from the Imperial Gate. The gifts of Maktûlzâde Ali Pasha, on the other hand, which seems even more unassuming than those of Ali and Numan, were also brought from the grand vezir's palace into the Imperial Palace humbly. The best man of the bridegroom (who was also the proxy), the steward of the grand vezir, and the steward of the bridegroom arrived together with the marriage attendants carrying trays.

${ }^{62}$ It is interesting to note that the halberdiers of the Old Palace were demoted in 1724. Their important role in the processions of 1708,1719 and 1710 could have been related to the presence of valide sultan at the time of these marriages. Even though she did not live there (her second son was then on the throne), she seems to have had the authority over the personnel at the Old Palace which was reserved for the mothers and women of the preceding rulers. Gülnûş Emetullah died in 1715. 
After she died in 1715, Damad İbrahim Pasha may have stepped in immediately to find husbands of his preference for any remaining royal princesses. Thus while Emetullah Gülnûş may have been keen to maintain the bonds between Mehmed IV and Mustafa II, on the one hand, and the Köprülüs on the other, the new grand vezir appears to have acted not only to block out the Köprülü descendants, but also to push a number of his own blood relatives onto the stage. He would get his chance in 1724 .

Third, in all earlier weddings, only routine (and minor) modifications took place in the parade order of the grandees and the number of attendants in their retinues. In contrast, the weight of the grand vezir's household made a quantum jump in 1724. This is consistent with all the other changes. The highlighting of the nişân processions taking off from the grand vezir's palace; the rise to prominence of the grand vezir's kith and kin, including two sons-in law as proxies or best men; the central role his household came to play in the entire pageantry-all these give the impression of converging to magnify the rising power of the Sublime Porte and of Damad İbrahim Pasha. This can perhaps be better seen by looking separately at several sub-components:

\section{a. The Grand Vezir's Palace}

Changes of this scope and magnitude cannot be attributed merely to the blood-ties between the grand vezir and two of the bridegrooms of 1724. Rather, what was placed center-stage and highlighted was the house and household, or the palace, of Damad İbrahim Pasha. It is true that regardless of its location the grand vezir's palace was traditionally the starting point of nişân processions. Still, İbrahim Pasha seems to have taken special advantage of this tradition in order to enhance his personal visibility, public presence, and institutional authority.

By 1724 the grand vezir and his royal wife had several palaces at different locations. Following their marriage in 1717, the one across from the Kiosk of Processions on the landwalls of the Topkapi Palace, which had long housed many grand vezirs, grew into a monumental complex as Damad İbrahim Paşa and Fatma Sultan continued to annex nearby palaces, and busied themselves with restoring and rebuilding them. ${ }^{63}$

${ }^{63}$ I have traced the history of the grand veziral palaces in the vicinity of the Topkap1 Palace from 1654 to 1730 , often referred to as no more precisely than "across from" or "below" the Kiosk of Processions: Tülay Artan, "The making of the Sublime 
The particular location of this compound, conveniently neighbouring the Topkapı Palace and the Hippodrome, as well as its layout and parts, all reflect Damad İbrahim's ambition of establishing his own conspicuous house and household. Its level of architectural grandeur and luxury is a question that needs to be addressed separately. In 1724 the grand vezir, like Sultan Ahmed III had done after the court resettled in İstanbul, made a determined move in strikingly overt fashion to inscribe his palace and himself into the capital as he orchestrated the various processions moving in and out of his residence.

But was this show simply a contingency arising from the swing of political fortune? Or did he really have in mind a permanent officeresidence to symbolize his power and commemorate his name? In other words, is it really possible to date the making of the Sublime Porte to Damad İbrahim Pasha's tenure?

\section{b. The Imperial Council}

A key historiographical weakness at this point is the prevailing and hardly explicable neglect of the Edirne episode, which began in the late 1650s and lasted for nearly five decades, and which then required the re-inscription of the court back into Istanbuliote space immediately after $1703 .{ }^{64}$ At least partly as a result of the comprehensive failure to deal with such a momentous interlude, the existing secondary (and encyclopedic) literature remains stuck in the assertion that it was (Nevşehirli) Damad İbrahim Pasha who played the decisive role in the finalization of the grand vezir's control of the Imperial Council (Divân-ı Hümâyûn); and in the transfer of its offices to the Sublime Porte. $^{65}$

Porte near the Alay Köşkü and a tour of a grand veziral palace at Süleymaniye', in: In Memoriam Stefanos Yerasimos 1942-2005, Çağatay Anadol, Edhem Eldem and Aksel Tibet, eds. (İstanbul 2011).

${ }^{64}$ Artan, 'Was Edirne a Capital'.

${ }^{65}$ With reference to Mehmed Süreyya's Sicill-i Osmanî (v. iv, 755), it was Deny who claimed that "the 'Porte', which at the same time was the personal dwelling of the Grand vezir and at the outset tended to be rather mobile, gradually lost the character of a semi-private residence and became finally established, under what was henceforth to be its official name, from 1718, when the Grand vezir Nevşehirli Damad İbrahim Pasha returned with his father-in-law, Sultan Ahmed III, from Adrianople to İstanbul, after the peace of Passarowitz”: Jean Deny, 'Bâb-1 Âlî', EI2, vol. 1, p. 836. See also: Metin Kunt, 'Sadrazam', EI2, vol. 8, pp. 751-752. For the description of the ethics and manners of the Grand vezir in early 18th century: Walter Livingstone Wright, Nesâyihü'l-vüzerâ ve'l-ümerâ (Princeton 1935); Abdülkadir Özcan, 'Şehid Ali Paşa'ya 
We know the grand vezirs to have supervised a hierarchically ordered staff of officials divided between the two main offices of the central administration: the Imperial Chancery and the Imperial Finance Bureau. The transformation in the status of the Imperial Chancery in particular is argued to have been achieved by Nevşehirli-as expressed in the bestowal of veziral status on three key officials who were thereby transformed into the three main agents of the grand vezir. These were his steward, the chief sergeant-at-arms, and the chief of the chancery clerks, who were respectively assigned to managing interior affairs, justice, and foreign relations, while only the chief treasurer, also known as the chief keeper of the registers (defterdâr-1 evvel or başdefterdâr), in his capacity as the custodian of imperial records, remained under sultanic jurisdiction. ${ }^{66}$

However, even as early as the 1650 s, there is evidence that the Imperial Chancery and its departments collectively referred to as the bureaus of the Imperial Council (divan-ı hümayûn kalemleri), had moved out of the Topkapi Palace and become part of the grand vezir's household. ${ }^{67} \mathrm{~A}$ related point is that the second main department, responsible for financial affairs, ${ }^{68}$ was separated from the grand vezir's authority at about the same time-in the 1650s, and not in the early 18th century. By 1724 İbrahim's ambition to expand and display his house and household was still centered on those offices that visibly came under the grand vezir's jurisdiction. Hence Damad İbrahim Paşa was emphatic about putting all this on show throughout the capital via the marching order, the ceremonial costumes and headgear, and the trappings of the horses of the members of his household.

İzafe Edilen 'Talimât-nâme’ye Dair', Tarih Enstitüsü Dergisi 12, Prof. Tayyib Gökbilgin Hatıra Sayısı (1981-1982) pp. 191-202. The latter was probably commissioned by Çorlulu Ali Pasha.

${ }^{66}$ Uzunçarşıll, Merkez ve Bahriye Teşkilâtı; Bernard Lewis, 'Dîvân-1 Hümâyûn', EI2, v. 2, pp. 337-339; Carter Vaughn Findley, Bureaucratic Reform in the Ottoman Empire. The Sublime Porte 1789-1922 (Princeton 1980); and also "Dîvân-1 Hümâyûn" in Bayerle, Pashas, Begs, and Effendis, pp. 38-39.

${ }^{67}$ See note 63 above.

68 The Office of the chief treasurer was called the Porte of the Register (Bâb-1 Defter). See: Joel Shinder, 'Career Line Formation in the Ottoman Bureaucracy, 1648-1750: A New Perspective’, JESHO XVI, Parts I-III (1973) pp. 217-237. 


\section{c. The Household}

He was also said to have led the way in inserting "his men" (i.e. members of his household) into the administration. Indeed, Damad İbrahim Pasha's focus on his household as a unit of possibly proto-dynastic organization in its own right was exceptionally ambitious.

When the decision on the marriage of three princesses was taken on 6 January 1724 (9 R 1136), all three bridegrooms were promoted. ${ }^{69}$ The grand vezir's son (Genç) Mehmed Beg, being only thirteen, had no official position at the time of his royal marriage. ${ }^{70} \mathrm{He}$ was made a pasha (of three horse-tails). Ali Beg, the grand vezir's nephew, had been a second master of the royal stables. He was first made the steward of the imperial gatekeepers (kethudâ-i bevvâbân-ı şehriyârî), and then received a further distinction as he became a vezir and a member of the Imperial Council. Hence, at the time of his marriage, he was called Tevkîî il Ali Pasha. Damad İbrahim Pasha's other nephew, (Küçük) Sinek Mustafa Pasha, a younger son of his brother Halil, (d. 1764), was also promoted with the title of beylerbeyilik prior to his wedding in 1728 . He, too, had been a second master of the royal stables at the time. ${ }^{71}$

All three blood relations survived the 1730 uprising while the grand vezir and his two in-laws were brutally murdered. Both Kethüda Mehmed and Kaymak Mustafa, respectively appointed on 27 March 1719 and 7 September 1721, had been hand-picked by İbrahim Pasha. The French authorities in İstanbul, relying on reports by the ambassador Marquis de Bonnac, noted that the grand vezir delegated great authority to his sons-in-law, and also included in his retinue the Chief of the Clerks (re'isü'l-küttâb), Üçanbarlı Mehmed Efendi (2 August 1718-18 October 1730); the Head of the Ulemâ (şeyhü'lislâm), Yenişehirli Abdullah (7 May 1718-30 September 1730); the Head of the Treasury (defterdâr), Hacı Türk İbrahim Ağa (9 May 1719-died in office in 1729); as well as Grigore Ghika, the Dragoman. ${ }^{72}$ In addition, it should also be noted that the Chief Physician (hekimbaşı), Hayâtîzâde Mustafa Feyzi Efendi (1724-1735); the Chief

\footnotetext{
${ }^{69}$ Mehmed Râșid, Tarih-i Râşid V, pp. 90, 96.

${ }^{70}$ Mehmed Râşid, Tarih-i Râșid V, pp. 90-92, 97-101.

${ }^{71}$ Artan, 'Yönetici Elitin Saltanatın Meşruiyet Arayışına Katılımı', pp. 292-322.

72 Schefer adds to this list also a certain Hac1 Mustafa: Schefer, Mémoire historique, pp. $\mathrm{xxx}-\mathrm{xxx}$.
} 
Black Eunuch (dârü's-sa'âde ăgası), Hacı Beşir Ağa (1717-1746); the Master of the Horse (imrahor), Haydar Ağa (1717-1726); and the Janissary Commander (yeniçeri ağası), Şahin Mehmed Ağa (1722-1731), all had unprecedentedly long tenures at this time. Taken together, this is quite an unusual and intriguing picture.

It is possible to deepen our understanding of this oligarchy with its intricate political relations, marriage alliances, and ties of patronage and clientelage. Lesser members of Damad İbrahim Pasha's household, for example, can be carefully identified from registers of allocations and household expenses. Upon closer examination, they, too, are found to be connected to all these high-ranking dignitaries. Exploring these, however, is beyond the limits of this study.

\section{d. Protocol}

The 17th century had constituted a long break with "Classical Age" customs and practices. The first half of the 17th century had been a time of instability, and over its second half Mehmed IV and his immediate successors had been forced to quit İstanbul for Edirne. What was lost in the process was reinvented in the Defter-i Teşrîfât of Mehmed bin Ahmed (Ni'metî), recorded by order of Mustafa II, and most probably elaborating on his father Ahmed Efendi's own work presented as law code (kanûnnâme). The section on ceremonies involving grand vezirs in the Teşrîfatî Mehmed's protocol register, along with borrowings from Lutfî Pasha's (d. 1563) Âsafnâme elaborating on the conduct of the grand vezirs has given rise to a claim that a grand vezir must have patronized this manuscript. ${ }^{73}$ This is not quite sustainable, for in the text there are explicit references not only to Mehmed IV but also, and much more emphatically, to Mustafa II: the former is blamed for his laxity with regard to rites and rituals, while the latter is clearly and repeatedly cited, praised, for being determined to remedy the situation.

${ }^{73}$ Karateke, An Ottoman Protocol Register, pp. 36-38. Karateke, dating Teşrifâtî Mehmed's register to early or mid-18th century, notes its difference from later registers of protocol: "in the later registers, entries for similar ceremonies repeat each other almost identically, unless unusual conduct had occurred," and concludes that "the later registers are but bureaucratic products of governmental offices". Karaca and Karateke located more than 50 registers of protocol. Karateke notes that in the 19th century, registers containing only one type of ceremony were put together. Thus, one such register contained only mevlid ceremonies; another which included weddings and circumcision ceremonies: BOA, Sadaret Defterleri 366 (1251-1308/1836-1891). 
Nevertheless, this is an understandable misinterpretation, for as with many other, comparable texts, Teşrifâtî Mehmed's work is also full of references to the crucial role of the grand vezir. Although we do not know the origins of the tradition, it is true that it had "always" fallen on the grand vezirs to orchestrate the weddings of royal princesses. ${ }^{74}$ It is interesting, for example, that information on wedding protocols can also be found in registers emanating from the office of the grand vezirate. ${ }^{75}$ So it is no surprise that the presence of the grand vezir should be so noticeable in 1675 , should have been restated in 1695, and should then have been felt even more strongly in 1708-for then, it was a matter of the grand vezir Çorlulu Ali Pasha himself marrying a princess. In 1709 and 1710, too, the processions more or less followed the same order.

Although we do not have a detailed account of the 1720 marriages, we know that Damad İbrahim Pasha was the mastermind behind the whole design. ${ }^{76}$ It is against this whole background of grand vezirial involvement that we have to assess İbrahim's specific role and contribution. He was not inventing an entirely new protocol, but he was subtly playing with what already existed, innovating here and there to enhance his own and his family's role. His interest in the "re-invention of tradition" over 1718-1730 extended not only to processions directly involving the grand vezir, but even royal princes' circumcision rites. It is safe to assume that he not only studied earlier sûrnâmes, and also built on them to elaborate his own design. Four years later, the bridegrooms were the grand vezir's own son and nephew, but it was not just this fact that stamped itself on the 1724 festivities. Rather, it was the evolution of a number of administrative offices of the Imperial Council and their progressive transfer into the grand vezir's household that was heavily reflected in these processions. Even more explicitly, what was involved was the (re)emergence of the grand vezir as the favourite

\footnotetext{
${ }^{74}$ Another compilation of protocol registers, dated to 1743 , was ordered from 'Abdullah Nâ'ilî Pasha by Mahmud I: 'Abdullah Nâ'ilî, Kavânîn-i Teşrîfat: Türk Tarih Kurumu Y. 49. The reason for this commission was, once again, the pressing need to organize the loose documents in the archives-likes of the 1724 sûrnâme. For excerpts: 'Abdullah Nâ'ilî, 'Dîvân-1 hümâyûna â'id teşrîfât', Türk Tarih Encümeni Mecmuasi 16 (1926) pp. 249-260.

${ }^{75}$ Başbakanlık Ottoman Archives, Bâbıâlî Evrak Odası (BEO) Sadâret Defterleri.

${ }^{76}$ For the transcription of Sûrnâme-i Vehbî by Mertol Tulum, see: Sûrnâme. An Illustrated Account of Sultan Ahmed III's Festival of 1720, Ahmet Ertuğ ed. (Bern 2000).
} 
and alter ego of the sultan. Thus while the nişân procession was dominated by the grand vezir's and the cihâz by the sultan's household, the arûs procession was in the nature of a display of the imperial apparatus incorporating the ministers of state (vüzerâ- $y ı$ izâm), religious scholars (ulemâ-yı kirâm) and the high-ranking state and court functionaries (erkân-ı devlet). Still, the grand vezir seems to have made a majestic display of his family and household on this occasion.

Küçük Çelebizâde, narrating the 1728 royal marriages, points out the role that the 1724 protocol was meant to play. He notes that Salihâ Sultan's bridal gifts were sent with a procession as designed in 1724. ${ }^{77}$ Then when the bride was taken to her palace at Eyüb, Küçük Çelebizâde remarks yet again that this was done in conformity with the "established procession" ${ }^{78}$ Likewise, in November 1728, he notes that Ayşe's and Zeynep's weddings at the Topkapı Palace was in the manner of "earlier accounts". ${ }^{79}$ Then, Ayşe's trousseau is also said to have been paraded in the manner of the "earlier accounts" ${ }^{80}$ It was only in the case of the transfer of Zeynep's troussau and her marriage procession to the Kıbleli Sarayı in December 1728, that Küçük Çelebizâde felt compelled to speak of a new development. ${ }^{81}$

\section{e. The Hippodrome}

Another exceptionally striking aspect of 1724 is the accentuation of the urban center, namely the Hippodrome, which had been completely left out of the ceremonial route in all previously recorded cases of royal marriages from the 16th century onwards. This denial must have

\footnotetext{
77 "bin yüz otuz altı târîhinde vâki" olan sûr-ı sultânî beyânında tahrîr olunduğu minvâl üzre alay-ı nezzâre-pîrâ ile."

78 "kevâkib-i dürriyye-i sipihr-ismet iffetlü sultânlarhazarâtının sarâyve makāmlarına

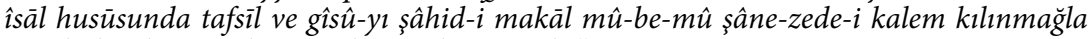
tatvîl olunduğu vech üzre alay-ı şehr-ârây ile."

79 "mukaddemâ vâki" olan akidlerde tafsìl-i keyfiyyet-i ahvâl olunduğu üslûb ve minvâl üzre."

80 "mukaddemâ tahrîr olunan alâylarda tafsīl olunduğu tertîb üzre alay ile."

81 "Zikr olunan alayda imâm-ı evvel ve sânî-i sultânî ve Hekîmbașı ve Cerrâhbaşı ve Haremeyn-i muhteremeyn müfettişi efendilerin örf ve üst kürkleri ile süvâr olmaları fermân ve Enderûn-ı Sarây-ı Hümâyûn ağaları ve hidmet-i Âsafîde olan Enderûn ağalarından gediklü ze'âmete mutasarrıf olanlar sâir zümreleri ricâli gibi mücevveze ve ferâce semmûr kürkler ve evkāf-ı selâtîn mütevellîleri ağalar perị̂̂̂nî ve ferâce kürkler ile râkib olup imâm-ı Âsafì efendinin Muharrir-i Fakìr ile horasanî destâr ve ferâce kürkler ve saçaklı ile hem-nâm olması istihsân buyurulmağla, mukaddem olan alay-ı vâlâdan zînet ve kesreti efzûn ve dü-bâlâ oldu."
} 
been all the more strongly felt since it was routine for the marriages of princesses to coincide with princely circumcisions. But while the latter took place in the Hippodrome, the former were excluded from it even in the early 18 th century, at a time when royal marriages were becoming part and parcel of public parades.

On the other hand, the relation of the Hippodrome to the grand vezirial palace had been established back in 1521-22 when Süleyman I's favourite İbrahim Pasha rebuilt, and settled in, a palace flanking its western side. In doing so, in his time he too appears to have aimed at enhancing his personal visibility and authority in the capital. ${ }^{82}$ In 1708 , while Emine's marriage processions took the shortest route to the palace of the grand vezir, we see that during the two following weddings there were attempts at coming close to the Hippodrome. However, they did not enter the large open space, the arena of Ottoman celebrations and public spectacle. In 1709, the procession of the trousseaus had to cross the city from one end to the other, and the procession taking the bride seems to have passed right by the Hippodrome: leaving the Imperial Gate, it went past the Cebehâne (St Irene), and from one end of the Hippodrome (At Meydanı başından), it went into the Dîvânyolu, from where it proceeded to Eyüb. During the 1710 marriage of Safiye Sultan, the procession of the princess passed through the same route, leaving the Imperial Gate, passing by the Cebehâne, and coming close to the Hippodrome (At Meydanina kârib mahalden), but did not enter the vast square, instead taking the Imperial Route (nehc-i şahî) of Soğukçeşme, by way of Alay Köşkü reaching the Râmî Pasha Palace at Demirkapi.

In Spring 1724, in contrast, İbrahim Pasha appears to have been keen to restore the Hippodrome back to its former centrality, though we shall never know whether he was consciously emulating his 16thcentury namesake in the process. For it is clear that whatever happened to be their final destination (the palace allocated to the newlywed couple), in 1724 all such processions had to (a) go through the Imperial Gate, (b) pass below the Alay Köşkü (for acclamation), (c) stop before the gate of the grand vezir's palace, (d) move on to Dîvânyolu, and

${ }^{82}$ İbrahim Pasha's own marriage there in the Spring of 1524 displayed unprecedented imperial grandeur-even though he was not marrying a princess, but the granddaughter of a grandee. For the political and ideological setting of İbrahim Pasha's palace (a rebuilding of the palace of janissary novices): Turan, Sultan's Favourite, pp. 145-179. 
then (e) enter the Hippodrome. It was only then, only from the center of this vast urban plaza, that the procession headed out again towards its eventual destination, whether it happened to be on the shores of the Golden Horn, or on the Marmara Sea, or in older and more traditional neighbourhoods.

Route of the

Alay-1 cihâz of Ümmügülsüm

Bâb-1 Hümayûn'dan çıkılıp

Cebehâne önünden

Ayasofya Hamamı önünden

Dîvânyolu'na gidecek dörtyol ağzına

bakkallar köşesinden dik aşağı

Soğukçeşme önünden

Alay Köşkü altından

Şengül Hamamı yokuşundan

Vezir-i azam[Sarayı'n]ın ard kapisindan

Sebil köşesinden sapılip

Dîvânyolu'na çıkıldıkta

Firuz Ağa Camii önünden

At Meydani'na

miyâne-i meydandan

Şeyhü'l-islâm Efendi'nin

bahçe duvarıyla

ard kapısı sokağından

Nahılbend Çarşısı'ndan

Çardaklı Hamamı önünden

Kadırga Limanı'na varulup

Alay-1 cihâz of Hadice

Bâb-1 Hümayûn'dan çıkılıp

Cebehâne önünden

Ayasofya Hamamı önünden mürûr

bakkallar köşesinden dönülüp

Soğukçeșme önünden
Alay-1 arûs of Ümmügülsüm

Bâb-1 Hümayûn'dan çıkılıp

Cebehâne önünden

Ayasofya Hamamı önünden

$=$

$=$

$=$

$=$

$=$

$=$

$=$

$=$

Talimhâne sokağından

At Meydanı'na

miyâne-i meydandan

Şeyhü'l-islâm Efendi'nin bahçe duvar1

sokağından

Nahılbend Çarşısı'ndan

Çardaklı Hamamı önünden

Kadırga Limanı'na varulup

Alay-1 arûs of Hadice

Bâb-1 Hümayûn

Cebehâne yolu ile

Ayasofya Hamamı önünden mürûr

Soğukçeşme'ye 
Alay Köşkü altından

Şengül Hamamı yokuşundan

Vezir-i 'azâm [Sarayı] ard kapisindan

Sebil sokağından

Çatalçeşme'den

Dîvânyolu'na

Dîvânyolu ile geri

Ayasofya Hamamı önünden

Cebehâne önünden

Saray Meydanı'na

Kaya Sultan Sarayı önünden

Kibleli Saray
Alay Köşkü altına varıldıkta

(alkış)

Şengül Hamamı yokuşu ile doğru

$=$

$=$

$=$

Dîvânyolu'na çıkıldıkta

Firuz Ağa Camii önünden

At Meydanı'na duhul

miyâne-i meydandan

Tavukçular Kârhânesi sokă̆ından

Arabacılar Kârhânesi önünden

Ahurkapı önünden mürûr,

Unluk Anbarı önünde meydanda

[Kıbleli Saray demekle meşhur]

saray-1 mezbura varıp

Alay-1 arûs of 'Atîke

Bâb-1 Hümayûn'dan çıkılıp

Cebehâne ve

Ayasofya Hamamı önünden mürûr

Soğukçeşme yolu ile

Alay Köşkü altına varıldıkta

(alkış),

Şengül Hamamı yokuşundan

Çatalçeşme önünden

Dîvânyolu'na

Firuz Ağa Camii önünden

At Meydanı'na çıkılıp

miyane-i meydandan

Kule Bostanı duvarı ile

Valide Hamamı önünden

Vezir Hanı'ndan

Cebecibaşı Sırrı Ağa hânesi önünden

Servi Mahallesi kurbundan

Cağaloğlu Sarayı yoluna

'Atîke Sultan Sarayı 
One can see on the map (Fig. 1$)^{83}$ what the overall historical and dynastic situation demanded of İbrahim Pasha. On the one hand, Ottoman imperial processions were occasions to show off the might of the Ottoman state, to renew it, and to display it to the people of the capital. On the other hand, as with all pre-modern and even most early modern societies, continuity (or at least a semblance of it) had to be protected and emphasized, since the established order resisted innovation. Any outright change or explicit "innovation" was considered tantamount to degeneration..$^{84}$ All this was largely concerned with the legibility and hence legitimacy of power relations.

\section{The Wedding Processions of 1724: Continuity and Change}

One of the least noted paintings of Jean-Baptiste Vanmour, a native of Valenciennes who lived and worked in İstanbul over 1699-1737, shows a procession of the grand vezir through the Hippodrome with the Sultan Ahmed Mosque on the left and the 16th-century palace of (Süleyman I's favourite) İbrahim Pasha on the right. (Fig. 2) It is a rare view of the urban center by an European artist. The grand vezir Damad İbrahim Pasha and his retinue of forty to fifty attendants are depicted as moving diagonally at one end of the vast empty space, approaching a free-standing fountain. They seem to be on their way either to the Topkap1 Palace or the palace of the grand vezir across from Alay Kösskü. A document relating to this painting, dated 1817, ${ }^{85}$ identifies the rider at the front of the procession as his steward and son-in-law (Mehmed Pasha), who is followed by a group of perhaps sixteen people, noted as his running footmen. They are wearing red kaftans with long hems tucked into the front of their belts, wide trousers to below the knee, yellow boots, and short kâtibî turbans, with white muslin wrapped bulbously around a short cap. Mehmed Pasha

${ }^{83}$ I am grateful to Ersen Kavaklı from Sabancı University Information Center and to my colleague Murat Güvenç and his team (Şehir Araştrımaları Merkezi, İstanbul Sehir University) for creating this map based on: Ekrem Hakkı Ayverdi, 19. Asırda İstanbul Haritası (İstanbul 1978).

${ }^{84}$ For a discussion of the problem of personal and dynastic legitimacy of the ruler in the Ottoman context particularly relevant to our case here see: Crane, 'The Ottoman Sultan's Mosques', pp. 193-201.

${ }^{85}$ For the document found in Rijksmuseum Archives: Eveline Sint Nicolaas, 'Old Archives, New Insights', in: An Eye Witness of the Tulip Era. Jean-Baptiste Vanmour, Eveline Sint Nicolaas et al., eds. (İstanbul 2003) pp. 103-135. 


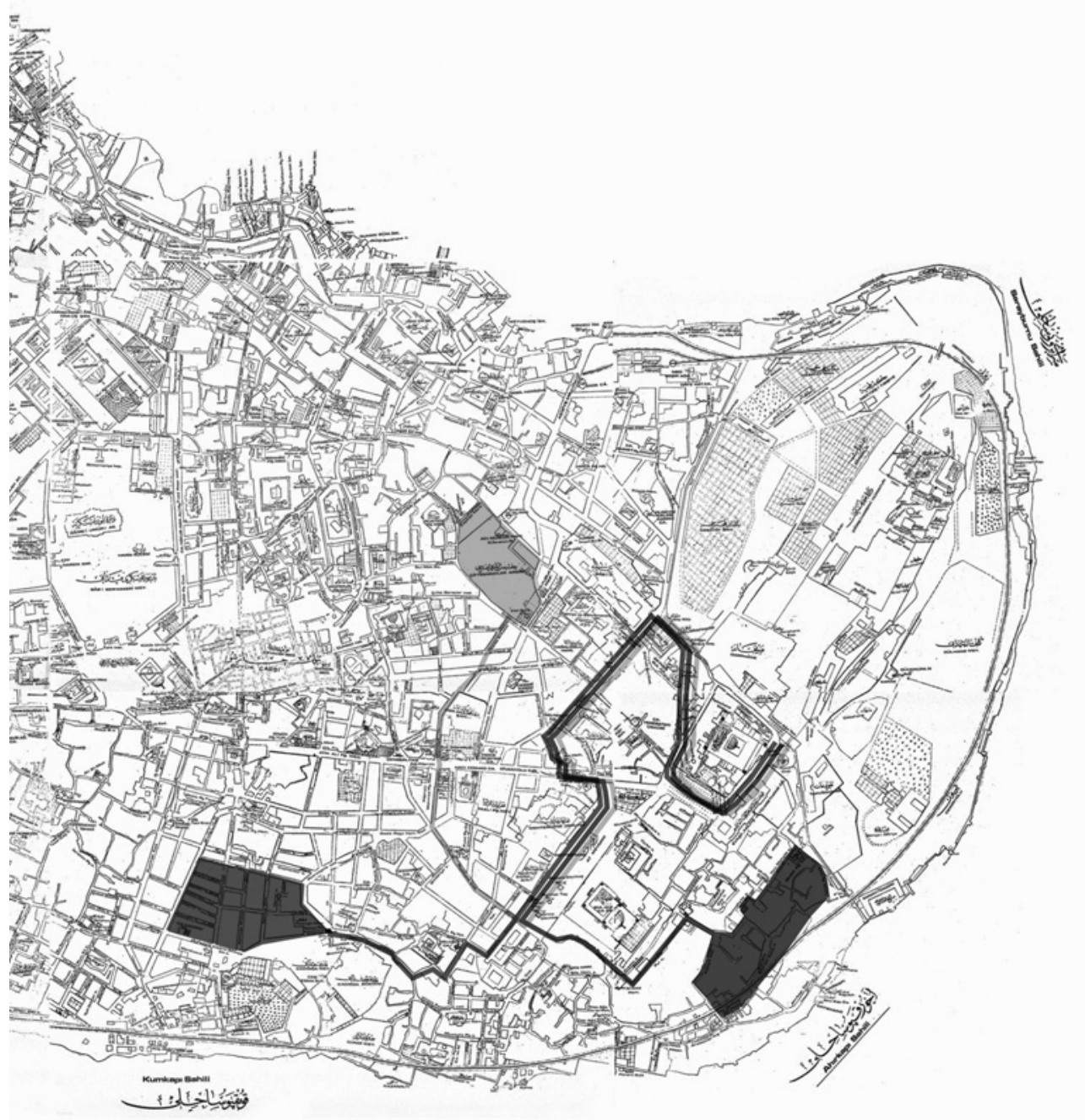

Figure 1. Map showing the routes of the 1724 processions. Reproduced from: Ekrem Hakkı Ayverdi, 19. Asırda İstanbul Haritası (İstanbul 1978). 


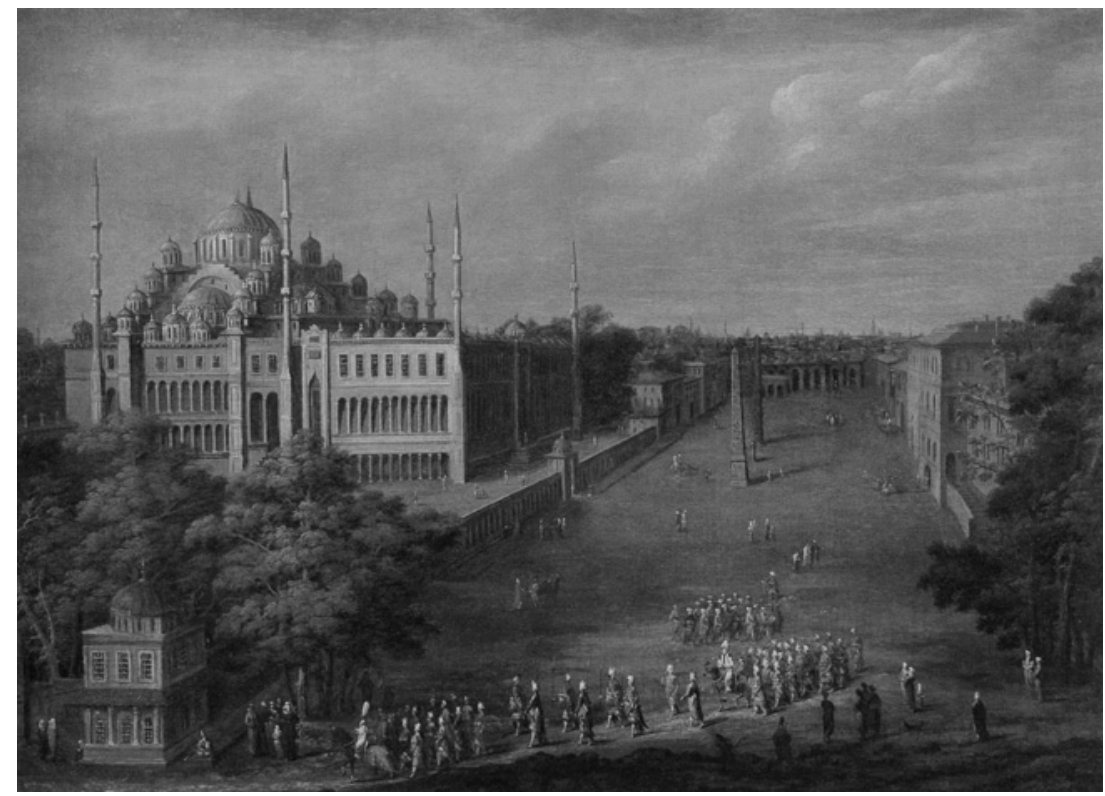

Figure 2. Damad Ibrahim Pasha's processions through the Hippodrome/ Atmeydanı by Jean-Baptiste Vanmour. SK-A-1998. Amsterdam, Rijksmuseum

wears a mücevveze, a tall ceremonial turban of many plaited folds, and a white ceremonial kaftan. Then comes another group of six, the şatırs or guards who are marked by the shiny pikes that they carry in a rather awkward manner. Wearing green kaftans also with long hems, turned up in front and tucked into their broad shimmering belts, these guards display gilded swords on slings as well as matchlock muskets. In addition, they too wear kâtibî turbans, wide trousers to below the knee, and yellow boots. This group is followed by another two wearing red kaftans of the same cut, each carrying a red bundle, perhaps a prayer rug and a cushion (to be used when the vezir had to kneel), and finally the grand vezir himself riding his horse. He is wearing a kallâvî, a tall ceremonial turban that only vezirs wore, and a white ceremonial kaftan with fur lining. He is followed by a rather unassuming rearguard of nearly two dozen attendants.

The narrator, perhaps a descendant of Cornelis Calkoen, the Dutch ambassador to İstanbul in 1727-1744 and a major collector of Vanmour paintings, explains that the prayer rug and the cushion would have needed to be used if the grand vezir was still out and moving about at prayer time. It is more likely, however, that Damad İbrahim 
Pasha is shown here on his way back from prayers at his recently completed socio-religious complex at Şehzâdebaşı. He is surrounded by his running footmen and followed by janissary guards: "They are always thousands, sometimes up to eight thousand men, that accompany him as such in the streets. Yet this crowd walks with extraordinary speediness, and one can hear the noise they create by running, from far away," says the author of the 1817 document, relating perhaps what he had heard from his ancestors. ${ }^{86}$

When it comes to providing a visual image of that "crowd", once more it is to Vanmour that we must turn again for a depiction of the majesty of the grand vezir's retinue-this time on another (unidentified) occasion. This, now, is not in an urban setting, though it might nonetheless be related to the wedding processions of 1720,1724 or $1728 .^{87}$ (Fig. 3) For his representations of such stately parades, including at least three which involve the sultan himself, Vanmour seems to have made use of a pictorial convention-one in which a procession begins in the foreground and then winds its way further and further back into and up the canvas. (Fig. 4) This allowed him to fit the whole procession into a single frame. At about the same time, the celebrated court artist Levnî was also capturing these imperial parades. His depictions of the various 1720 processions, however, are linear, and have therefore to be spread over several pages. In the past, Ottoman artists had not paid much attention to urban pageants. Now, however, the new rites and ceremonies launched by Ahmed III upon his return from Edirne to İstanbul, together with a new marriage policy involving royal women, seem to have caught their interest. ${ }^{88}$

\footnotetext{
${ }^{86}$ Actually, the most interesting feature in the painting is the walking style of the attendants: they seem to have been paired, and half-turned to one another, they appear to be carefully orchestrating their steps. This marching mode is not noted elsewhere. There is a reference, however, to a certain pâsdâr makam in the company of which the procession of the troussau of Safiye Sultan marched to her palace on 1 May 1710: TSM Archives D. 10591.

87 Olga Nefedova, A Journey into the World of the Ottomans. The Art of Jean-Baptiste Vanmour (1671-1737) (Milan 2009) p. 134. For other processions including those of the sultan depicted by Vanmour, see pp. 134-137. For another rare depiction of the grand vezir and the grand admiral parading through the city: Nikolaus Kleeman, Tagbuch der Reisen (Prague 1783) p. 388 from Gravürlerle Türkiye III. İstanbul (Ankara 1996) p. 139.

${ }_{88}$ Esin At1l, Levni and the Surname. The Story of an Eighteenth-Century Ottoman Festival (İstanbul 1999) pp. 112-143 (157b-174a) and 234-241 (12b-16a).
} 

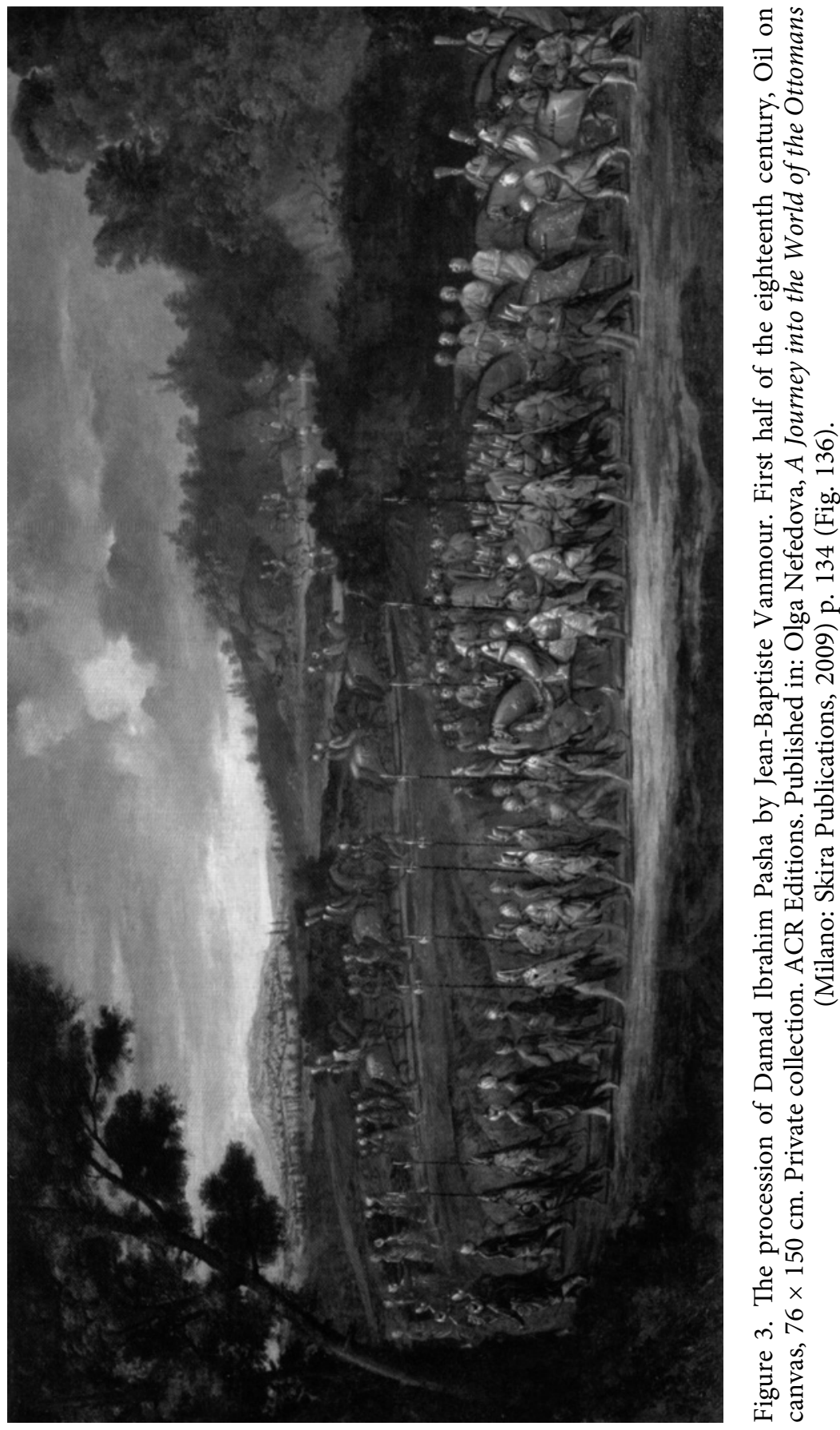


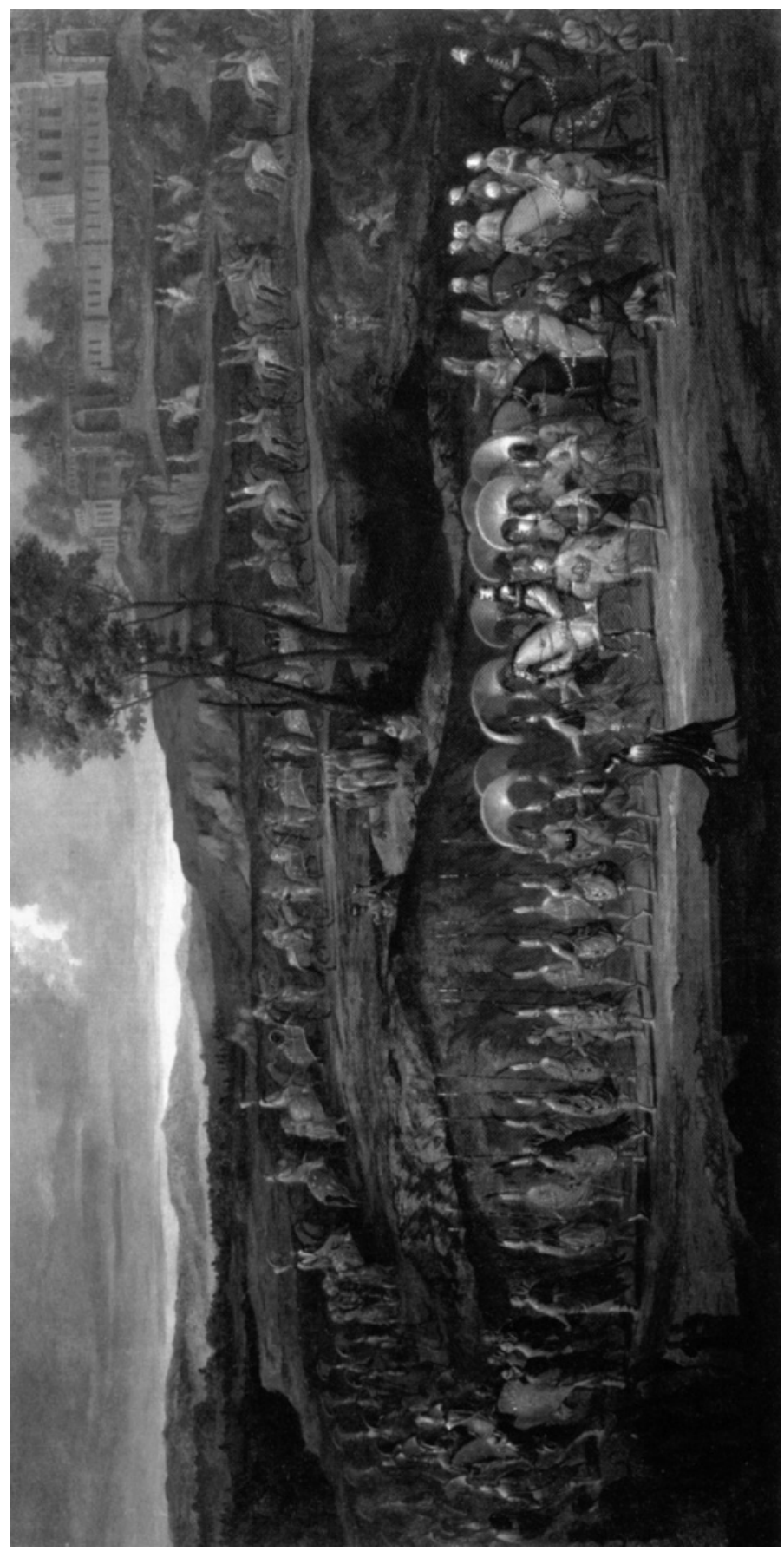

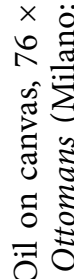

$\therefore \frac{\pi}{2}$

茪尔

过

东

楁

$\stackrel{2}{\frac{1}{2}}$

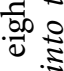

ذें

पू है

䒕

๘匠

फ़्ट के

社

$\div$.

崩

공

สิ

○.

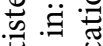

훙ㅁㅇ

$\infty \frac{1}{3}$

:

बै

ते

三

目.옹

멍

证

运全

4

ㄷำ

드으

क

$\stackrel{\infty}{=}$

\%

है

章

है

E

म

¿ ह

항요 
We have seen that from 1718 onwards, Damad İbrahim Pasha became a part of this project in many ways. With what seem to have been his proto-modern aesthetics and his organizational talents, his feel for both neatness and magnificence, he seems to have studied the ceremonies and festivities of the 16th-17th centuries in order to arrive at an acceptable format for something that was not a simple revival but part of a new social reality, a different historical epoch. ${ }^{89}$ İbrahim Pasha's solution was to establish or consolidate a route that had two components: a common element that was a solemn state occasion, and a second part that depended on the procession's destination. In between, the Hippodrome became the hinge and hence (once more) the center of urban festivals. The first part involved a procession allowing for a general display of rank and status (including especially the grand vezir's household). As a result, these royal weddings became both private-family and public-dynastic affairs. And in the end, it was this established route and its repetition that imprinted all these complex messages on the collective memory of İstanbuliotes. The Hippodrome, the single most important arena of public space where the sultans came for selective encounters with the populace, was reinvented in the festive atmosphere of the early 18th century.

This ceremonialization coincided with Ahmed III's and his grand vezir's grand design to re-assimilate the power being accumulated by the administrative elite. Together they took the major step of allowing,

${ }^{89}$ Thus, no matter how the programmatic functions of double or triple marriages of the royal daughters and nieces went far beyond a kind of one-dimensional dynastic aggrandizement, the established order of the processions were not challenged. No deviation was allowed. It has been repeatedly recorded in the Books of Protocol that they turned to the "kânûn-ı kadìm" whenever a marriage or circumcision was planned. As we have noted above Damad İbrahim Pasha, too, ordered the earlier Books of Festivals in 1720 and studied them carefully. Moreover, Râşid records that his predecessor Şehid (Silâhdâr) Ali Pasha also studied the books of protocols and that he had intended to revive the tradition of büyük kol, which was the grand vezir's visiting of the yeniçeri ağasi on the third days of the religious festivals. The chronicles records that Ali Pasha had to give in because of the financial dire straits, but his successor ordered to observe this procession in 1721. Thus Merzifonlu Kara Mustafa Pasha's waterfront palace at Eyüb was assigned for this ceremony which continued thereafter: Mehmed Râşid, Tarih-i Râşid V, p. 308. As Mehmed IV's master of ceremonies Ahmed bin Mehmed Ni'metî Efendi claims that it was Merzifonlu who had initiated the ceremony in 1677 (possibly in Edirne), it is safe to say that it was during the successive terms of Köprülü Mehmed and his son Ahmed that the stately rituals were neglected and the new grand vezir was in search of a revitalization. Moreover, Uzunçarşll remarks that the office of the master of ceremonies was also shifted to the Sublime Porte during the reign of Ahmed III: Uzunçarşıll, Merkez ve Bahriye Teşkilâtı, pp. 58-59, 144. 
indeed inciting royal women to engage in public manifestations of dynastic sovereignty on their own. They thereby interpolated them between the throne and the aspirations of (the rest of) the political elite. A crucial factor in this attempt to subdue the elite was the delegation of the sultanic prerogative of constructing palaces in the capital for princesses. These waterfront-palaces on the Golden Horn and the Bosphorus architecturally and symbolically put their husbands in their place by dwarfing their adjacent and much more modest residences. They also displayed and represented the dynasty as a whole. Such quasi-royal and sub-royal edifices were in turn followed and emulated by the summer houses of a whole host of lesser dignitaries, retired jurists, judges and Islamic scholars plus guild administrators, nonMuslim merchants, goldsmiths, moneylenders, and physicians who were closely connected with the court. Thus first the Golden Horn proved to be a extensive urban plaza for stately gatherings, entertainments, and processions (as was the case in 1720), and then the Bosphorus, gently winding its way from one pond-like bay to another, evolved into a new ceremonial avenue lined with large and small kiosks.

While princesses continued to be married to grandees and then settled in their waterfront palaces throughout the 18th century, it is striking that no urban-scale marriage ceremony was organized in the post-1730 period. It is therefore not surprising that after the 1743 compilation of 'Abdullah Nầilî Pasha's Kavânîn-i teşrîfât (The Laws of Protocol), no other pre-Tanzimat registers, including even the defter of 1736-1808, cover betrothal, trousseau or brides' processions. The atmosphere surrounding the 1720,1724 and 1728 royal weddings was lost. Ironically, in the 19th century it would be only princesses' funerals which kept being recorded in Ottoman chronicles and protocol registers. ${ }^{90}$

\footnotetext{
${ }^{90}$ Karateke, Ottoman Protocol Register.
} 


\section{Appendix I: Alay-1 Nişân of Ümmügülsüm, 'Atîke and Hadice?91}

The first of the processions on 20 February 1724 (25 CA 1136), on the occasion of the transfer of the betrothal gifts of Ali and Mehmed (and Ahmed?) from the grand vezir's palace to the Topkapi Palace, was led by the Grand Admiral Kaymak Mustafa Pasha. The grand admiral (a Köprülü descendent and a son-in-law of the grand vezir) was the best man of the grand vezir's nephew Ali Pasha (who was marrying Ümmügülsüm). ${ }^{92}$ Although the grand admirals had enjoyed this honour on previous occasions, it seems that in this case it was not only Kaymak Mustafa Pasha's office, but also his private relation to the grand vezir which was being highlighted by placing him at the head of the procession. ${ }^{93}$ He rode a horse with opulent trappings of the kind used by members of Imperial Council on the days of their official meetings.

Then came the head saddler (sarrâçbaşı) ${ }^{94}$ marching together with the water-bottle carriers (matharaci) and the musketeers (tüfengci), who may have constituted the close body-guard in the grand admiral's immediate retinue. ${ }^{95}$ Behind them was the commander (steward)

91 Codex Vindobonensis Palatinus OH 95, 65a-70b.

92 Artan, 'Yönetici Elitin Saltanatın Meşruiyet Arayışına Katılımı', pp. 292-322.

93 In the marriages of Emine and Fatma, then grand admiral İbrahim Pasha was the best man of Çorlulu Ali Pasha. For Safiye's husband Maktûlzâde Ali Pasha, it was Süleyman Pasha, a member of the Imperial Council, who was chosen as his proxy and best man.

94 I was not able to locate the head saddler in Damad İbrahim Pasha's household accounts. For the ceremonial roles of this office-holder (in relation to the yeniçeri ă̆ası and sekbanbaşı) see: Hezarfen Hüseyin Efendi, Telhîsü'l-Beyân, pp. 145, 149. Uzunçarşılı refers to the head saddler only in one instance, during the routine inspection of the grand vezirs on the third day of the religious festivals (büyük kol) and notes that he marched in front of the grand vezir together with the orta çavuşu: Uzunçarşılı, Merkez ve Bahriye Teşkilâtı, p. 144. His functions are not described in Gibb and Bowen either who nevertheless include the head saddler with the Masters of the Horse: H.A.R. Gibb and H. Bowen, Islamic Society and the West. A Study of the Impact of Western Civilization on Moslem Culture in the Near East I (Islamic Society in the Eighteenth Century Part I) (London; New York; Toronto 1950) p. 355.

95 The text identifies these three as attendants in the retinue of the grand admiral (rikâblarında olan). Uzunçarşılı refers to the matharacıbaşı and tüfengcibaşı within the ceremonial retinue that accompanied the grand vezir on the days of the Divan (and when he visited the şeyhü'l-islâm): Uzunçarşılı, Merkez ve Bahriye Teşkilâtı, p. 146. Gibb and Bowen, quoting D'Ohsson and Osman Nûrî, note that the two officers of the muhzir ăgas orta, called tüfengcibaşı and matharacıbaşı marched on either side of the grand vezir when he went on his rounds: Gibb and Bowen, Islamic Society and the West, p. 325, n. 5. 
of the gatekeepers (kapıcılar kethudâsi), who acted as the master of ceremonies. ${ }^{96}$ Marching next to him was another attendant of ceremonies (selâm ağası) whose regular duty was to escort the master of a household. ${ }^{97}$ Altogether this group of five, all mounted, were actually the aghas of the imperial stirrup (rikâb-ı hümâyun $)^{98}$ who served in immediacy to the sultan and attended him during processions as chief guards and officers of ceremonies. ${ }^{99}$ At the same time, together with many other functionaries who were gradually shifted from the Court to the Porte and began to serve in the capacity of middlemen between the sultan and the grand vezir while still stationed at the sultan's palace,

${ }^{96}$ The stewards of the doorkeepers (responsible for the guardianship of the Imperial Gate and the Gate of Salutation) were also a member of the sultan's "agas of the stirrup" and served at the Imperial Council in some ceremonial capacity. The kânûnnâmes of Abdurrahman Pasha and Hezarfen Hüseyin Efendi both of which describe the ceremonies before the reign of Mehmed IV refer to him as receiving the dignitaries entering the second courtyard, and gives further particulars of his duties at the Imperial Council meetings: Tevkîî̀ Abdurrahman Paşa, 'Kanunnâme-i Âl-i Osman', p. 506 ff and Hezarfen Hüseyin Efendi, Telhîsü'l-Beyân, pp. 74-79, 259-262, 264. See also: Uzunçarşıll, Osmanl Devletinin Saray Teşkilâtı, pp. 392-396. By the 18th century, they were copied as the majordomo in the grandee palaces modeled on the imperial palace while they ceased to be ranked aghas of the stirrup owing to the fact that their duties came to be connected more closely with the grand vezir than with the sultan: Gibb and Bowen, Islamic Society and the West, p. 83, and n. 7. It was the special duty of the kapicilar kethudâsı to carry memoranda (telhis) from the grand vezir to the sultan on these occasions. With the transfer of the Imperial Council to the grand vezir's residence, the ceremonial duties of the kapıcılar kethudâsı must have been observed at the Sublime Porte, but whether his various functions at the imperial palace were discontinued or not requires further elaboration.

${ }^{97}$ Uzunçarşıl is the only secondary source that refers to documents that identify selam ağası in the retinue of the grand vezir: Uzunçarşıll, Merkez ve Bahriye Teşkilâtı, pp. 132, 201. Moreover, selam ăgast is listed in Damad İbrahim Pasha's household accounts as a member of his retinue: Başbakanlık Arşivi Cevdet Dahiliye 6611 ( $\mathrm{R} 1134$ ).

${ }_{98}$ Hezarfen Hüseyin Efendi (who refers them also to özengi ağas) notes their number as 60 , and lists their majors as the agha of the Janissaries, the mir'alem, the kapıcubaşıs, the [two] mîrâhûrs, the çakırcıbaşı, the çaşnigirbaşı and the bölük ağas, all of those who personally assisted the sultan in mounting his horse: Hezarfen Hüseyin Efendi, Telhîsül-Beyân, pp. 92, 85. To these listed above the kapıcılar kethudâsı and the çavuşbaşı are added in other sources. See also: Gibb and Bowen, Islamic Society and the West, pp. 82-83, n. 2.

${ }_{99}$ For general information on these functionaries (originally) serving at the Topkap1 Palace see: Uzunçarşıll, Osmanlı Devletinin Saray Teşkilâtt: sarraçbaşı: 492-494, matharacı[başı]: 397, tüfengci[başı]: 326, kapıcılar kethudâsı: 392-396, selâm ağası (duacı çavuş): 419. As the host happens to be the grand vezir here, there is also the possibility that the functionaries listed here represents the grand vezir's householdhis household was a replica of the imperial palace. 
we find the five also listed in the grand vezir's household accounts. ${ }^{100}$ Here, however, they were organized around the grand admiral.

Next marched the Kethudâ Beg, the steward of the grand vezir and his chief secretary in/for internal affairs, who clearly marks the household of Damad İbrahim Pasha. The position of Kethudâ Beg (who was emerging as a minister of the interior) has been noted as "the product of an unusual evolution" in the household of the grand vezir in the early 18th century. ${ }^{101}$ Actually, the office in question seems to have been part of the grand vezirate since the mid-17th century. In this particular case, Kethudâ Mehmed Efendi was another son-inlaw of the grand vezir, and was also the proxy and best man of both the grand vezir's son Mehmed Pasha (who was marrying 'Atîke) and Ahmed Pasha (who was marrying Hadice). ${ }^{102}$ His horse was embellished with sumptuous trappings that were used on Imperial Council meeting days.

Then came the guide, the marshal leading the procession ( $k u l a g u z$ çavuş), conventionally a member of the sultan's household troops whose duty was to keep the route open and thus direct the march. ${ }^{103}$ There would be an officer serving in the same capacity in vezirial households,

${ }^{100}$ For a complete list of the functionaries in the enderûn and bîrûn quarters of Damad İbrahim Pasha in early 1722: Başbakanlık Arşivi Cevdet Dahiliye 6611 (R 1134). Among those listed here only the tüfengcis are missing in Damad İbrahim Pasha's household records. It is important to note that in 1676, they were not listed in the household of the grand vezir either. Compare with Kara Mustafa Pasha's household: Galland, İstanbul'a Ait Günlük Hatıralar II, pp. 132-136.

${ }^{101}$ Uzunçarş1l, Merkez ve Bahriye Teşkilâtı, pp. 256-59. "He had begun as a domestic functionary, managing the grand vizier's household and lacking any official character. At the Sublime Porte, he became an official of high status, serving the grand vizier as a kind of deputy, though he was not to be confused with the kaymakam or lieutenant appointed during the grand vizier's absences from the capital in wartime. The responsibilities of the steward are usually described as having to do with internal and military affairs. Beyond this sources on the eighteenth century disagree as to the details of his role or the roster of officers who came under him": Findley, Bureaucratic Reform, p. 73.

${ }_{102}$ Codex Vindobonensis Palatinus OH 95, 69b.

${ }^{103}$ It was not the kılaguz çavuş, but an alay başçavuşu who was listed in the retinue of Damad İbrahim Pasha in 1722, for keeping the route of the processions unobstructed. Hezarfen refers them as part of the marshals (çavuşan): Hezarfen Hüseyin Efendi, Telhîsü'l-Beyân, p. 146. Gibb and Bowen identify twelve alay çavuşes in the grand vezirial households who directed the march on occasions of public procession: Gibb and Bowen, Islamic Society and the West, p. 362, n. 6. In 1709, it was the regiments of the muhzır ağa, a member of the janissaries at the Imperial Court, who kept the route unobstructed and thus lead the procession, together with the 'asesbaşı and sübaşı. See also: Uzunçarşıll, Merkez ve Bahriye Teşkilâtı, p. 283. 
and this one seems to have been attached to the grand vezir's household. Behind him was the steward of Ümmügülsüm Sultan who led the betrothal gifts of Ali Pasha. The gifts of the bridegroom included twenty small nahıls, decorative structures made out of (silver) wires symbolizing fertility and good fortune, carried by colonels, that is to say orta-commanders (çorbacı) of household troops (the janissary corps) lined in pairs, ${ }^{104}$ followed by thirty exquisitely decorated trays carried by guards (nigâhban), said to be worthy of kind consideration (vâcibü'r-ri'âye), all dressed in white and in new boots. Theirs is a curious identity. While the 1708 and 1710 sûrnâmes are silent about them, in 1709 this group was explicitly noted as belonging to the grand vezir's household (sadrazam hazretlerinin vâcibü'r-ríâye ağaları). Each tray held three boxes of candies with delicately coloured coverings ( $p$ uşide). Then came two trays of sugar gardens (şeker bağçeleri) and a small nahıl of (solid?) silver. To the left of this nahıl a silver tray, crowned by a jewelry box, was paraded. Then there were four more silver trays, each carried by the chief gatekeepers (kapıcıbaşı ağas) of the grand vezir's palace, ${ }^{105}$ displaying the gifts of the bridegroom Ali Pasha. Each kapıcıbaşı ağa was escorted by two guards (nigâhban) who were again praised as worthy of kind consideration, again dressed in white. These could have been the lesser blood relatives of Damad İbrahim Pasha, or else youngsters or regular attendants.

Among the gifts on these trays were a jeweled belt, a diamond tiara, a set of rings and bracelets, a pair of large earrings with diamonds and emeralds, a jeweled mirror, pairs of various shoes to be worn indoors, outdoors, and in wet and slippery areas (papuç, mest, nalın), a diamond aigrette ( $\operatorname{sorguç)}$, and a diamond belt (çaprast). Each of the four

${ }^{104}$ It is not clear whether in later times these soup men, soup purveyors, cooks and scullions were still functioning in the capacity that their titles imply, or acted also or, exclusively, as subordinate commanders. For more see: İsmail Hakkı Uzunçarşıll, Osmanlı Devleti Merkez Teşkilâtından Kapıkulu Ocakları I (Acemi Ocağı ve Yeniçeri Ocağı) (Ankara 1988 [1943]); Gibb and Bowen, Islamic Society and the West, pp. 61, 319-20.

${ }^{105}$ For kapıcıs and kapıcıbaşıs see: Uzunçarşı1lı, Osmanlı Devletinin Saray Teşkilât, pp. 396-407, and idem, Merkez ve Bahriye Teşkilâtı. The number of kapıcıs reached 2000 by mid-17th century. At about this time, there were nine kapicıbaşıs under the supervision of a başkapıcıbaşı. In the course of the 18th century the numbers of the kapıcıbassis were in constinuous increase-reaching 60 at the beginning and 150 at the end of the century. But the kapıcıs and kapıcıbaşıs listed here in the 1724 wedding were identified as those serving in the capacity of guards and attendants of ceremonies that have been attached to the grand vezir's household which was modeled on that of the sultan. For more: Gibb and Bowen, Islamic Society and the West, p. 347. 
trays was made of 500 dirhems of silver (a dirhem equals 3,207 gram). ${ }^{106}$ Then the steward of Ali Pasha marched. The document continues with a brief reference to the gifts of Mehmed Pasha paraded in the same order. There is neither an extensive account of this succeeding procession, nor any mention of the third bridegroom, namely Ahmed Pasha and his gifts for Hadice.

The procession, comprising the high-ranking members of the two best men's retinues (hazerât), and a crowd of elite guards chosen from the private entourage of the grand vezir, entered the palace from the Imperial Gate, and a series of rituals took place in the palace. ${ }^{107}$ It is in this section of the sûrnâme that Ahmed Pasha's absence is made clear: as attested by the steward and another dependent of Ahmed Pasha, as well as the Re'is Efendi and the Çavuşbaşı, Kethüda Mehmed was made the proxy and best man of both Ahmed and Mehmed pashas. The sultan's gifts to the three bridegrooms were received, and the marriage contracts were signed. ${ }^{108}$

After the ceremony at the Imperial Palace came to a conclusion, the grand vezir left his palace together with the top-ranking state dignitaries. Led by the marshal serving as the guide (kulaguz çavuş), the envoy including the scribes and the treasurers of the marshals of the court (çavuşân), mounted their horses and rode to the Topkapı Palace. Then the director of the imperial chancery ( $\left.r e^{\prime} i s\right)$, the chief sergeant-atarms (çavuşbaşı), the janissary agha and the chief treasurer (defterdâr) marched. At the end of the procession was the grand vezir and the şeyhü'l-islâm. The magnitude and the composition of these dignitaries' retinues was not indicated in the sûrnâme.

${ }^{106}$ Küçük Çelebizâde Âsım Efendi's account differs slightly. He says that each vâcibü'r-ri'âye carried a tray with a silver box of sweets, candies and other sugar assortments. The contents of the four trays were not specified, but he remarks that these were followed by two gold trays each carrying 2,000 tuğralı altun (also known as cedid zolota or cedid Eşrefî) as mihr-i mu'accel, that is the part of the dowry, mandatory in Islam, which is given by the groom to the bride at marriage.

107 Codex Vindobonensis Palatinus $\mathrm{OH}$ 95, 67b-70b: Both the engagement and marriage ceremonies of the three couples were on the same day.

${ }_{108}$ With 10,000 altın mihr-i müeccel, the other part of the dowry agreed to be given to the wife if she is widowed or divorced: Codex Vindobonensis Palatinus $\mathrm{OH} 95$, 68a, 69b. Küçük Çelebizâde confirms the amount of mihr-i müeccel as 10,000 tuğralı altun. 


\section{Appendix II: Alay-1 cihâz of Ümmügülsüm}

On 28 February 1724 ( $3 \mathrm{C} 1136$ ), the trousseau of the princess was transferred from the Topkap 1 Palace to her palace at Kadırga Limanı. Now, it seems that court functionaries took over the grand vezir's household (which, a week earlier, had led the way to the Imperial Palace). First marched the marshal leading the procession (kulaguz çavuş), and then the captains of the mounted guards and troops who served as a police force ('asesbaşı ${ }^{109}{ }^{\left.\text {sübaş }{ }^{110}\right)}$ ). All were wearing their special costumes for Imperial Council meetings (kisve-i dîvâniye), and were followed by their respective corps wearing their regular felt headgear (keçe). Then came the marshals of the imperial palace, those guards or messengers of the sultan who regularly served as his escorts in official ceremonies (çavuşân-ı dergâh $-\iota$ 'âlî), ${ }^{111}$ to be followed by more such attendants, marshals of his standing cavalry corps (çavuşân- $\iota$ sipâh and silâhdâr). ${ }^{112}$ The ceremonial escorts and the court cavalry were cited by their headgear.

109 The 'asesbaşı was traditionally the bölükbaşı of the 28th bölük of the Janissary Corps. He was the second of the officers (after muhzir ağa) under whose supervision sentences were carried out; he was the chief of the night patrols of İstanbul and also the superintendent of public prisons in İstanbul. It was his duty to keep the streets clear of impending crowds on festive occasions and stately processions (including the routine inspections of the grand vezir-kola çıkma): Uzunçarşılı, Merkez ve Bahriye Teşkilâtı, p. 142; Gibb and Bowen, Islamic Society and the West, pp. 325-26; Bayerle, Pashas, Begs, and Effendis, p. 11. For their roles in the 1675 festival see: Hezarfen Hüseyin Efendi, Telhîsül-Beyân, pp. 153, 238, 241-42.

110 The subaşı was the commander of a subdivision of sipâhîs exercising the functions of the police as distinct from their military duties. He was the third of the officers (after the muhzır ăga and the 'asesbaşı) under whose supervision sentences were carried out. He marched in the processions together with the 'asesbaşı to keep the streets clear: Uzunçarşıll, Merkez ve Bahriye Teşkilâtı, p. 142; Gibb and Bowen, Islamic Society and the West, p. 324. For their roles in the 1675 festival see: Hezarfen Hüseyin Efendi, Telhîsül-Beyân, pp. 238, 241-42.

${ }_{111}$ The çavuşes of the Imperial Council served as escorts in official ceremonies as well as personal guards for ambassadors, and as messengers, as diplomatic envoys, and when needed, as executioners of high officials condemned to death. Their numbers reached 1000 by mid-17th century: Bayerle, Pashas, Begs, and Effendis, p. 29. See also: Uzunçarşıll, Merkez ve Bahriye Teşkilâtı; Gibb and Bowen, Islamic Society and the West, pp. 87, 327-28.

112 Another group of çavuşes served in the 5th bölük of the Janissary Corps and carried the orders of the commanders to the troop officers and performed various services as marshals: Bayerle, Pashas, Begs, and Effendis, pp. 29-30. For sipâhîs and silâhdârs see also: İsmail Hakkı Uzunçarşılı, Osmanlı Devleti Teşkilâtından Kapukulu Ocakları II (Cebeci, Topcu, Top Arabacıları, Humbaracı, Lağımcı Ocakları ve Kapukulu Süvarileri) (Ankara 1988 [1944]), pp. 146-50; Gibb and Bowen, Islamic Society and the West, pp. 69-71, 327-28. 
The composition of the next group is interesting. These were the exclusive members of the court elite, [the sons of the] select cavalrymen (gediklü zü'emâ-i müteferrikagân), ${ }^{113}$ the so-called trustees (ümenâ), ${ }^{114}$ and the scribes (bureau chiefs) of the imperial chancery (hâcegân), ${ }^{115}$ who were traditionally under the jurisdiction of the sultan. They were all on horseback. At this point, Küçük Çelebizâde Âsım Efendi also lists the treasurer of the sergeants (çavuşlar emîni) and his secretary as among the chiefs of the grand vezir's household (sâhib-i devlet ağalart). A lot of these were part of a quasi-nobility that subsisted on fiefs, while others were part of clerical services that were in transition from the Imperial Council to the grand vezir's palace. By that time, council meetings were taking place in the grand vezirial palace, and the

113 The honorific rank of müteferrika is a designation reserved for distinguished servants of the sultan. Angiolelo, an Italian page attached to Mehmed II's court, reports that the members of this motley group receiving monthly wages included the sons of nobles and defeated monarchs, physicians, astrologers, architects, engineers, painters, goldsmiths, jewellers, and other artisans: Gülru Necipoğlu, The Age of Sinan. Architectural Culture in the Ottoman Empire (London 2005) p. 153. Literally meaning "separated," müteferrika is thought to have been applied to men of guard employed on special duties: "they serve no one but the Imperial Council and the Sultan, and the road to advancement for them leads to the vezirate". Foreigners referred to them as the sultan's noble bodyguard. Their duties ranged from serving as mounted escorts to the sultan to carrying messages between the grandees. They accompanied him on military campaigns, but performed no military service. Only the member's of the sultan's Privy Chamber, the sons of eminent servitors, and exceptionally, the relatives of tributary rulers, were admitted to the corps: Gibb and Bowen, Islamic Society and the West, pp. 87-88, 328.

114 Plural of emîn, which means men entrusted with some property as intendants, stewards, keepers, custodians and trusties. Hezarfen notes the intendants of the city (şehremîni), the Arsenal (tersane emîni), Kitchen (matbah emîni), the barley (arpa emîni) and the biscuits (peksimet emîni): Hezarfen Hüseyin Efendi, Telhîsüll-Beyân, pp. 97-98. To these listed above the intendants of the mint (darbhâne emini), the cannon foundry (tophâne nâzırı) and the secretary of the royal expenditures (masraf-ı şehriyâri) should be added. See also: Uzunçarşıll, Merkez ve Bahriye Teşkilâtı, pp. 68-69; Gibb and Bowen, Islamic Society and the West, pp. 84-86. For the emins referred in the household accounts of Damad İbrahim Pasha, namely emîn-i kâtib-i çavuşan, emîn-i kâtib-i gedükliyan, emîn-i hesab, emîn-i şa'ir and emîn-i saman: Başbakanlık Arşivi Cevdet Dahiliye 6611 (R 1134).

${ }_{115}$ Referred in the 1709 procession as aklâm haceleri, that is to say clerks of the government offices, these were the senior scribes of the imperial chancery: Uzunçarşll, Merkez ve Bahriye Teşkilâtl, pp. 68-71. "In the 16th century 25 scribes had the title bestowed on them annually by the sultan upon the recommendation of the sultan...In 1732 the divan had 50 secretaries, 20 apprentices and 30 candidates": after Bayerle, Pashas, Begs, and Effendis, p. 72. For the politization of the Chancery as a result of the unfavourable diplomatic climate and the transfer of the ambitious hâcegân to the Chancery as the critical career step: Itzkowitz, 'Eighteenth Century Ottoman Realities', passim; Shindler, 'Career Line Formation', p. 221. 
Imperial Council Hall of the Topkapı Palace had already turned into a stage setting for certain ceremonial occasions such as the distributions of wages to the troops, receptions of foreign envoys, or celebrations of religious festivities. Nevertheless, the functioning of these officers at the Imperial Council in the grand vezir's palace in 1724 requires further investigation, even though at the time those listed above were included in Damad İbrahim Pasha's household accounts.

In due course came the sultan kethüdalar, the stewards of the princesses, who were all high-ranking dignitaries. Later in the document Ümmügülsüm Sultan's steward is clearly identified as marching together with the steward of the bridegroom. Hence, an all-inclusive reference to the princesses' stewards is rather misleading. These must be the stewards of Hadice and 'Atîke, and perhaps of all other princesses of the time. They were all on horseback and their horses were armored. These stewards are not mentioned by Küçük Çelebizâde. In the sûrnâme, they were followed by the mounted chiefs of the household troops (the janissary corps), namely captains of the cart-artillery (top 'arabacılarbaşı), the artillery (topçubaşı), the armory (cebecibaşı), the imperial hunters-head keeper of the hounds (zagarcıbassi) and keeper of the sultan's mastiffs (samsuncu) - and others who together formed the council (dîvân) of the janissary corps (ocak), all in their ceremonial divvân attires. ${ }^{116}$ Küçük Çelebizâde identifies the latter as saksoncu (which translates as the keeper of the hounds from Saxony), and also adds the head of the turnacis to this group. This last person took care of the dogs trained to hunt game birds such as cranes. The hunting establishment, originally a palace organization, was a regiment of the janissary corps. ${ }^{117}$ Then came the deputy to the janissary commander (kul kethudâsı) ${ }_{118}^{118}$ the secretary of the janissary corps (yeniçeri

116 Uzunçarşıll, Kapukulu Ocakları II. See also: Gibb and Bowen, Islamic Society and the West, pp. 315-316.

117 The seksoncıbassı, literally the head dog-keeper, was in command of the zagarcıs (greyhound-keepers), samsoncus (mastiff-keepers), and turnac1s (keepers of the cranehunting dogs): Uzunçarşıll, Kapukulu Ocakları I, pp. 199-204; Gibb and Bowen, Islamic Society and the West, p. 315.

${ }^{118} \mathrm{Kul}$ kethudâsı was the deputy of the Janissary commander and was third in rank in the Janissary corps after the segbanbaşı. However, kul kethudâsı (a title probably abbreviated from kapıkulu kethudâsı) who was in command of the bölük representing the force first used as a body-guard for the sultan at his head-guards (therefore the kapıkulus par excellence), enjoyed a much greater esteem than the segbanbaşı, second place in the Janissary hierarchy: Uzunçarş1l, Kapıkulu Ocakları I; Gibb and Bowen, Islamic Society and the West, pp. 314-315. 
efendisi), ${ }^{119}$ the senior deputy to the janissary agha (segbânbaşı), the stewards of the commanders of the cavalry regiments (sipâh and silâhdâr kethüdalari), the mounted messenger (atlu mukabeleci) and his scribes, the commanders of the cavalry regiments themselves (sipâh ağa and silâhdâr ağa), and chiefs of the imperial hunt (şikâr-ı hümâyûn ağas). ${ }^{120}$ Küçük Çelebizâde identifies these as the head keepers of the goshawks and the peregrine falcons (çakırcıbaşı and şahincibaşı). At first glance these military officers, chiefs, commanders and captains all appear as representing the sultan. However, there were also those who acted as intermediaries between their regiments (ocak) and regimental subgroups on the one hand, and the Sublime Porte on the other. Therefore their presence and position in the procession could be "read" in a different way. ${ }^{121}$

Next in line were the high-ranking functionaries of the Imperial Court such as the chiefs of the gatekeepers (kapıcıbaşı ağas). Even though it is not explicitly stated (as opposed to the previous procession, where it was noted that those in question were attached to the grand vezir's household), it is likely that the gatekeepers listed here did represent the sultan and the court. Following them came high-ranking bureaucrats of the Imperial Bureau of Finances: the keeper of the [land/ cadastral] registers (defter emini), and the chief treasurer (başdefterdâr or defterdâr-1 evvel), who had remained under the authority of the sultan although they were the first to move out of the palace, and the latter's two aides (defterdâr-1 şıkk-ı sânî and şıkk-ı sâlis). ${ }^{122}$

In due course the commander in chief of the janissaries (yeniçeri ağa) appeared. Apart from being a military commander, the head of the janissaries was also something of a police officer and was therefore responsible for the maintenance of law and order and the protection

119 The secretary, who was not a janissary himself, kept the rolls with the assistance of a large group of clerks: Uzunçarşıll, Kapukulu Ocakları I, pp. 386-90; Gibb and Bowen, Islamic Society and the West, p. 316, n. 6.

${ }_{120}$ Also referred as ser-şikârî: Uzunçarşılı, Kapukulu Ocakları I, pp. 229-30; Gibb and Bowen, Islamic Society and the West, p. 321.

${ }^{121}$ In this group of intermediaries Uzunçarşılı lists: muhzır ağa, bostancılar odabaşısı, kethudâs of sipâh and silâhdâr bölüks, kapı çavuşes of the cebecis, topçus, toparabacıs, 'asesbaşı, sübaşı, müteferrikabaşı: Uzunçarşll, Merkez ve Bahriye Teşkilâtı, p. 172.

${ }_{122}$ The separation of defterdâr kapısı is a debated issue. It is dated either to the end of the 16th century or to the creation of the grand vezir's separate office in mid-17th century. For the debate see: Fodor, 'Sultan, Imperial Council, Grand vizier', p. 73, n. 15. For the "organizational components of the Sublime Porte" see: Findley, Bureaucratic Reform, pp. 70-79. 
of property in most of İstanbul proper (excluding Eyüb, Üsküdar, and Galata). In the heart of the capital, only the sultan's palace and an adjacent quarter were outside his jurisdiction. ${ }^{123}$ This last neighbourhood as well as the outlying belt around the capital were under the control of other military officers (such as the topçubaşı and the cebecibaşı). ${ }^{124}$

Then came the grand admiral in his capacity as the best man of Ali Pasha, followed by his sword-bearer (silâhdâr) and the keeper of his seal (mühürdâr), his spare horse, and his master of protocol (teşrîfâtî̀). ${ }^{125}$ The stewards of the bridegroom and the bride came after the grand admiral and his retinue.

Next in line were more functionaries of the Imperial Court: the master of the stables (mîrâhur-ı evvel ăga), riding a horse in ceremonial trappings, was followed by thirty aghas (eunuchs) of the Imperial Harem, who bore cages displaying precious items of gold and silver. Then came the second master of the horse (mîrâhûr-ı sân $a \breve{g} a$ ), riding together with the head of the military band of the tentpitchers (hayme-i hassa mehterbaşı). The seven files of mules (70 in all) carrying the trousseau were escorted by the corps of tent-pitchers (mehteran neferatı), and two senior tent-pitchers (mehter odabaşı) were assigned to each file. Finally, eleven carriages carrying the female attendants (kapakl arabalar), and the standard-bearer of the mehter (mehterhâne-i mîr-i âlem ağa). Küçük Çelebizâde adds that at the end of the procession was the chief of the sultan's military band (çalicl mehterbaşısı ăga $)$ and his band (mehterhâne-i padişâhî).

${ }^{123}$ Gibb and Bowen, Islamic Society and the West, p. 66.

124 İstanbul, divided into the four judgeships of İstanbul and bilad-ı selase (Eyüb, Galata and Üsküdar), was policed by soldiery under the command of no less than five officers, the limits of whose respective jurisdictions did not coincide with those of these judgeships. Those part of the capital under the jurisdiction of the agha of the janissaries, the topçubaşı and the cebecibaşı were confined to İstanbul itself, and part of the judgeship of Galata. Referring to Osman Nurî, Gibb and Bowen records that while Pera and Beyoğlu were under the jurisdiction of the topcubaşı, the quarters of Ayasofya, Ahurkapı and and Hocapaşa were controlled by the cebecibaşı: Gibb and Bowen, Islamic Society and the West, pp. 66-69, 323.

${ }^{125}$ Küçük Çelebizâde Âsım Efendi does not list the members of the grand admiral's retinue. 


\section{Appendix III: Alay-ı arûs of Ümmügülsüm}

Finally, two days later, on 2 March 1724 (6 C 1136), which was a Thursday, Ümmügülsüm was taken from the Topkapı Palace and transported to the Kadirga Palace. This final procession included the sultan, the grand vezir and their households, as well as members of the ulema, and various formalities were observed along the way, such as an elaborate acclamation in front of Alay Köşkü. Küçük Çelebizâde notes that the procession of dignitaries followed "the previously established order" (ricâl-i devlet bi'l-cümle tertîb-i sabık üzre). ${ }^{126}$ In addition to the household troops (janissary corps), he also mentions the chiefs of the imperial guards (solakbaşı ağas) as passing on horseback.

The 1724 sûrnâme provides us with all the details. Again at the head of the procession were the chiefs of the imperial guards and their retinues: kulaguz çavuş was followed by the 'asesbaşı, sübaşı, çavuşân-ı dergâh-ı 'âlî, and çavuşân-ı sipâh and silâhdâr. While we find that the chief of the sergeants had exchanged his felt cap for a turban of many plaited folds and was also wearing an official fur coat, the rest of the lead group was once again described only by their headgear.

Then came the aghas of the grand vezir. Their presence at this point confirms that the group which followed, namely the quasi-nobility of the Imperial Council's gedikli zü'ema-i müteferrikagân, once again riding armored horses with sumptuous trappings, were really those who had already been transferred to the grand vezir's palace. The aghas in question were probably the grand vezir's chief gatekeepers.

The procession continued with the princesses' stewards (sultan kethudâları), ümenâ and hâcegân. In due course the chiefs of the artillery and armory followed. These were: the steward of the cart-artillery (toparabacı kethudâsı) and his sergeant (çavuş); [then probably their captain (top 'arabacılarbaşı)]; the steward of the artillery (topçular kethudâsı) and his çavuş; the captain of the artillery (topçubaşı); the steward of the armorers (cebeciler kethudâsi) and his çavuş; and the captain of the armorers (cebecibași). As mentioned above, these were the intendants, chiefs and captains who represented their corps

126 The janissary commander was followed by the chiefs of the finance bureau and the top members of the religious establishment: the defterdâr and the inspector of the Haremeyn treasury, and the judge of İstanbul, representative at İstanbul of the Sherif of Mecca (nakîü̈l-eşrâf efendi, who was also the chief of the descendants of the Prophet) and the two military judges of Anatolia and Rumelia (sadreyn efendis). 
(ocak) at the Sublime Porte. They were followed by more military staff ranging from the officers of the janissary regiments (yeniçeri zâbitân) to the affiliates known as the camel-drivers (deveciler). Then in due order came the chief sergeants (başçavuş) of the hound-keepers (samsuncu, zagarcı), and the kul kethudâsı, the standing cavalry of the court (sipâh and silâhdâr), the mounted messenger (atlı mukabeleci) and his scribes, the chiefs of the standing cavalry (sipâh and silâhdâr ă̆as), and the heads of the imperial hunt (şikâr-ı hümâyûn ağas).

Then came the gatekeepers and their chiefs: kapıcıbaşı ağas and kethudâ-i bevvabin. ${ }^{127}$ As mentioned above, these two were traditionally members of the sultan's household, but those represented here may have actually been the members of the grand vezir's palace-the steward was explicitly mentioned in the nişân procession. This is further confirmed by the fact that the functionaries of the state under the grand vezir's command, namely his chief secretary and his two aides, the first and second secretaries to the grand vezir (mekt $\hat{u} b \hat{\imath}-i$ sadr$\hat{a} l i$; tezkere-i evvel and tezkere-i sânî), were introduced immediately afterwards. ${ }^{128}$ Then came the keeper of the [land] registers and his two aides (defter emîni; şıkk-ı sânî and şıkk-ı sâlis), and the chief treasurer (defterdâr efendi) who remained under the authority of the sultan even after the transfer of the chancery offices of the Imperial Council to the grand vezir's palace. ${ }^{129}$

After the commander of the janissaries (yeniçeri ağasi), who seems to have been marching in line with the chief treasurer (başdefterdâr or defterdâr-1 evvel), members of the 'ulemâ made their first public appearance in these processions: the inspector of the treasury of Mecca and Medina (haremeyn müfettisii), the chief of the descendants of the Prophet (the nakîbü'l-eşrâf, the Mecca sheriff's representative in İstanbul), the chief judge of İstanbul as well as the supreme judges for Anatolia and Rumelia who, of course, were permanent members of the Imperial Council (and were collectively called sadreyn efendiler).

Then came Ali Pasha, the bridegroom on horseback, though he was mistakenly referred to as Ahmed Pasha. (Küçük Çelebizâde repeats

${ }_{127}$ Uzunçarşılı, Osmanlı Devletinin Saray Teşkilâtı, pp. 392-407; and idem, Merkez ve Bahriye Teşkilâtı, pp. 132, 138, 201.

${ }_{128}$ Uzunçarşıll, Merkez ve Bahriye Teşkilâtı, pp. 55, 260-261.

129 In 1709 , it is noted that from the muhzır ağa to the yeniçeri ağası, the hierarchy that was observed in the procession of the trousseaus was repeated in the procession of arûs. The household of the grand vezir, including the çavuşbaşı, re'isü'l-küttâb, and tezkerecis, followed the yeniçeri ağası and preceded the members of the ulema. 
the same confusion.) He was followed by a row of dignitaries who, except for the steward of the grand vezir and, of course, the grand admiral, were those members of the Imperial Council who had been already incorporated into the grand vezir's household. ${ }^{130}$ Following the steward of the grand vezir, and then the grand admiral, and after him the second bridegroom Mehmed Pasha, there came the chief of the imperial chancery clerks $\left(r e^{\prime} i s\right),{ }^{131}$ and the chief sergeant of the Imperial Council (çavuşbaşı). ${ }^{132}$

Then rode the grand vezir himself escorted by the muhzır ağa, who was posted as aide-de-camp to the office of the grand vezir, ${ }^{133}$ and by the senior officer of the imperial gardeners (bostancilar odabaşısi), who in that capacity was also the commanding officer of the imperial guards. ${ }^{134}$ To the left of the grand vezir was the şeyhü'l-islâm wearing

${ }^{130}$ For the incorporation of the Imperial Council in the Bâb-1 Âlî by mid-17th century as a result of centralization and increase in paper work see also: Recep Ahıskalı, Osmanlı Devlet Teşkilatında Reisülküttâblık (İstanbul 2001); Ahmet Mumcu, Hukuksal ve Siyasal Karar Organı Olarak Divan-ı Hümâyûn (Ankara 1986).

${ }^{131}$ Halil İnalc1k, 'Reisülküttâb', İA IX, pp. 671-683. For a through study of the office: Ahıskalı, Reisülküttâblık. For the role of the re'is efendi in state ceremonies, especially in the dynastic marriages see: pp. 230-322, in particular pp. 309-311.

132 The commander of the çavuşes of the divan who was present in the divan meetings and was in charge of the protocol: Uzunçarş1l, Osmanl Devletinin Saray Teşkilâtt; and idem, Merkez ve Bahriye Teşkilâtt; Gibb and Bowen, Islamic Society and the West, pp. 349-50; Bayerle, Pashas, Begs, and Effendis, p. 30. See also: Murat Uluskan, Dîvân-ı Hümâyûn Cavuşbaşılı̆̆ı (XVI-XVII. Yüzyıllar), unpub. MA Thesis, MÜSBE Türkiyat Araştırmaları Enstitüsü (İstanbul 1998). Referring to two types of çavuşes, those of pay-drawers and those that subsisted on fiefs, Gibb and Bowen remark: "What is certain is that as time went on both were supplanted as couriers by other functionaries-kapıcıbaşıs, hasekis and müteferrikas, and that apart from their continued participation in the sultan's public processions, they came to be attached to the service of the grand vezir (who eventually discharged all the sultan's other public duties) rather than that of the palace. Hence the loss of the "stirrup" rank by the çavuşbaşı and his classification by D'Ohsson as a minister of state rather than a court official. That he continued to act jointly with the kapıcılar kethudâsı as master of ceremonies at divans did not mean that he was thereby properly a member of the Outside Service, since the divans were now presided over not by the sultan, but by the grand vezir."

${ }_{133}$ The muhzır ağa who was one of the bölükbaşıs of the janissary corps acted as the liason between the office of the grand vezir and the Janissary corps. In other words, as he was the representative of the janissaries in the grand vezir's household, janissaries from his bölük guarded the grand vezir's quarters: Uzunçarş1l, Merkez ve Bahriye Teşkilâtı, pp. 138-39, 142, 144; Gibb and Bowen, Islamic Society and the West, p. 325; Bayerle, Pashas, Begs, and Effendis, p. 112.

${ }_{134}$ Uzunçarşıll, Kapıkulu Ocakları I. Wearing a simple külah, a seraser kuşak and red çuka dolama, the bostancis were recruited from the acemis, and formed a training pool of the janissary corps while performing manual labour in the palace gardens. The bostancıbaşı, the commander of the bostancı corps, was one of the officers who was close to the sultan, holding his stirrup: Bayerle, Pashas, Begs, and Effendis, p. 23. 
a fur-lined white broadcloth cloak ( ferâce) as well as a special turban (örf) worn only by the leading judiciary and the sultan. Then the grand vezir's sword-bearer (silâhdâr-ı sadr-ı âlî), wearing a sable fur and with a jeweled sword over his shoulder, walked side by side with the keeper of the grand vezir's seal (mühürdâr- $\iota$ sadr-l $\hat{a} \imath \hat{\imath}) .{ }^{135}$ Next were the grand vezir's two spare horses, followed by the retinue of the muhzır ağa.

There marched the master of ceremonies of the Imperial Council (teşrîfât-ı dîvân-ı hümâyûn). He was followed by the stewards of the bridegroom (damad paşa kethüdast) and of the bride (sultan kethudâsi), who walked at the head of a couple of hundreds of sailors from the arsenal (tersâne bahadırları), who filed past in pairs carrying their campaign pikes, followed by their captains (kaptan). ${ }^{136}$ After a group of carpenters and two large nahıls, in this case tall decorative trees paraded as symbols of fertility, came the chief architect (mi'mâr $a \breve{g} a$ ), the chief of the Imperial Kitchens who was assigned to supervise the nahıls (nahıl emîni olan matbah-ı âmire emîni Halil Ağa), and the steward of the arsenal (tersâne kethudâsı). We are given to understand that all three had been employed in the making of the nahils.

Next were the spare horses of the princes, and the first and second masters of the horse (mirahur-ı evvel and mirahur-ı sâni ağas). The four princes (Süleyman, Mehmed, Mustafa and Bayezid), all followed riding their highly decorated horses, each accompanied by a pair of imperial guards (rikâb solak).

Then came another prominent member of the Imperial Court, the chief black eunuch of the Topkapı Palace (dârü's-sa'âde ağası), Hacı Beşir Ağa, surrounded by numerous attendants, and by a show of pomp and circumstance. His retinue was followed by six small nahils and then a silver nahil. Then came the silver carriage of the princess drawn by six horses, followed by other imperial carriages. At the end of the procession was the standard-bearer of the household troops (mîr-i âlem a $\breve{g} a$ ), and the head of the military band (çalıcı mehterbaşı ağa), leading the entire military (mehter) band. When the grand vezir appeared, as he came abreast of Ahmed III, the çavuşes acclaimed the sultan.

${ }^{135}$ Küçük Çelebizâde Âsım Efendi identifies this mühürdâr as Mustafa Ağa (who had replaced çukadâr ağa).

${ }^{136}$ Küçük Çelebizâde Âsım Efendi remarks that there were 400 soldiers from the Arsenal (tersane huddamları). Their costumes were in bright colours. They carried two, huge nahils. 